ARTICLE

\title{
Essential dynamic interdependence of FtsZ and SepF for Z-ring and septum formation in Corynebacterium glutamicum
}

Adrià Sogues (10 1, Mariano Martinez', Quentin Gaday', Mathilde Ben Assaya1, Martin Graña (D) 2, Alexis Voegele (10 ${ }^{3}$, Michael VanNieuwenhze (1) ${ }^{4}$, Patrick England ${ }^{5}$, Ahmed Haouz (1) ${ }^{6}$, Alexandre Chenal (1) ${ }^{3}$, Sylvain Trépout (iD ${ }^{7}$, Rosario Duran (i) ${ }^{8}$, Anne Marie Wehenkel (i] ${ }^{1 \times} \&$ Pedro M. Alzari (iD ${ }^{1 \times}$

The mechanisms of Z-ring assembly and regulation in bacteria are poorly understood, particularly in non-model organisms. Actinobacteria, a large bacterial phylum that includes the pathogen Mycobacterium tuberculosis, lack the canonical FtsZ-membrane anchors and Z-ring regulators described for E. coli. Here we investigate the physiological function of Corynebacterium glutamicum SepF, the only cell division-associated protein from Actinobacteria known to interact with the conserved C-terminal tail of FtsZ. We show an essential interdependence of FtsZ and SepF for formation of a functional Z-ring in C. glutamicum. The crystal structure of the SepF-FtsZ complex reveals a hydrophobic FtsZ-binding pocket, which defines the SepF homodimer as the functional unit, and suggests a reversible oligomerization interface. FtsZ filaments and lipid membranes have opposing effects on SepF polymerization, indicating that SepF has multiple roles at the cell division site, involving FtsZ bundling, Z-ring tethering and membrane reshaping activities that are needed for proper Z-ring assembly and function.

\footnotetext{
${ }^{1}$ Unité de Microbiologie Structurale, Institut Pasteur, CNRS UMR 3528, Université de Paris, 75015 Paris, France. ${ }^{2}$ Bioinformatics Unit, Institut Pasteur de Montevideo, Montevideo 11400, Uruguay. ${ }^{3}$ Unité de Biochimie des Interactions Moléculaires, Institut Pasteur, CNRS, UMR 3528, 75015 Paris, France. ${ }^{4}$ Department of Chemistry, Indiana University, Bloomington, IN 47405, USA. ${ }^{5}$ Plate-forme de biophysique moléculaire, C2RT-Institut Pasteur, CNRS, UMR 3528, 75015 Paris, France. ${ }^{6}$ Plate-forme de cristallographie, C2RT-Institut Pasteur, CNRS, UMR 3528, 75015 Paris, France. ${ }^{7}$ Institut Curie, INSERM U1196, CNRS, UMR 9187, Université Paris-Sud, Université Paris-Saclay, 91405 Orsay, France. ${ }^{8}$ Analytical Biochemistry and Proteomics Unit, Institut Pasteur de Montevideo \& Instituto de Investigaciones Biológicas Clemente Estable, Montevideo, Uruguay. ${ }_{\text {email: anne-marie.wehenkel@pasteur.fr; pedro.alzari@pasteur.fr }}$
} 
T he prokaryotic tubulin homolog FtsZ is at the heart of bacterial cytokinesis. At the cell division site, FtsZ protofilaments form a highly dynamic, membrane-bound structure, the Z-ring, which serves as a scaffold for the recruitment of the extra-cytoplasmic cell wall biosynthetic machinery. Despite its discovery $>25$ years ago $^{1}$, the exact molecular mechanisms of Z-ring assembly and regulation remain enigmatic ${ }^{2}$. In the best studied organisms, such as Escherichia coli and Bacillus subtilis, the action of several auxiliary proteins is necessary to positively or negatively regulate Z-ring formation (EzrA, ZapA- ${ }^{3-7}$ ), to tether the structure to the membrane (FtsA, ZipA, SepF ${ }^{8-11}$ ), and to ensure proper subcellular (mid-cell) localization $\left(\operatorname{Slm} A, \mathrm{Noc}, \mathrm{MinC} / \mathrm{MinD}^{12-14}\right)$. Most of these proteins exert their functions by binding directly to the highly conserved FtsZ $\mathrm{C}$-terminal domain $\left(\mathrm{FtsZ}_{\mathrm{CTD}}\right)^{15}$, which is separated from the core GTPase domain by an intrinsically disordered linker of variable length and sequence. Except for SepF, all the above positive and negative FtsZ regulators are missing in Actinobacteria ${ }^{16}$, for which cell division mechanisms are largely unknown.

The sepF gene is found in the $d c w$ (division and cell wall) cluster along with fts $Z$ and many essential genes for cell divi$\operatorname{sion}^{17}$. In B. subtilis, SepF is a non-essential membrane-binding protein that co-localizes with FtsZ at mid-cell and is required for correct septal morphology as part of the late divisome ${ }^{18,19}$. In contrast to B. subtilis, sepF is an essential gene in Mycobacterium smegmatis $^{20}$ and in the cyanobacterium Synechocystis ${ }^{21}$, both of which lack an identifiable homolog of ftsA. In M. smegmatis SepF localizes to the Z-ring in a FtsZ-dependent manner and has been shown to interact with the conserved C-terminal domain of FtsZ in yeast-two-hybrid assays ${ }^{20}$. Like FtsA, SepF has self-associating properties $^{22}$ and thus appears as a likely candidate for FtsZ membrane tethering in Actinobacteria. However, the observed assembly of SepF into stable $50 \mathrm{~nm}$ diameter ring polymers (alone or by bundling FtsZ protofilaments) seems to lack the dynamic oligomerization properties that are a recurrent feature of divisome and Z-ring interactors ${ }^{23,24}$. Indeed, increasing evidence suggests that membrane anchors are not just passive but active players of Z-ring dynamics and regulation. For instance, FtsA has a dual role both serving to tether FtsZ filament fragments to the membrane and exercising an antagonistic function on polymerization dynamics and directional assembly at mid-cell, a prerequisite to robust proto-ring assembly and subsequent inwards growth of new cell wall ${ }^{10,24,25}$. While in B. subtilis FtsA and SepF may have complementary and partially overlapping functions ${ }^{11}$, we asked what happens in species where only SepF is present as a major Z-ring membrane anchor. Here, we provide mechanistic insights for the FtsZ-SepF interaction and its interdependency for Z-ring assembly and septum formation in C. glutamicum. We show that SepF has a complex dynamic role at the division site and that the ternary interaction between SepF, FtsZ, and the membrane, coupled to FtsZ polymerization dynamics, are all required for proper function and assembly.

\section{Results}

The essential role of SepF in C. glutamicum. SepF from $M$. smegmatis was shown to be essential for viability and this protein was indeed proposed to be the unique membrane anchor for FtsZ in Actinobacteria ${ }^{20}$. However, an early study reported that the $s e p F$ gene was not essential in Corynebacterium glutamicum ${ }^{26}$, which would argue against a main membrane tethering role for SepF. Several attempts at deleting sepF from C. glutamicum using either homologous recombination or gene disruption failed, suggesting that this gene might indeed be essential for bacterial survival. To deplete sepF we designed a conditional mutant strain $\left(P_{\text {ino }}\right.$-sepF) where the transcription of sepF was uncoupled from its physiological promoters by placing a transcriptional terminator just before the sepF gene, and by putting it under the control of the previously described myo-inositol repressible promoter $\left(P_{\text {ino }}\right)$ of the inositol phosphate synthase Inol gene ${ }^{27}$. Down-stream effects were not expected as $s e p F$ is the last gene to be transcribed in the $d c w$ cluster in C. glutamicum ${ }^{28}$. We observed a rapid depletion of SepF in the presence of $1 \%$ myoinositol, while in its absence the SepF protein levels remained close to the level in the wild-type (WT) strain (Fig. 1a). The growth curves of the depleted $P_{\text {ino }}$-sepF and WT strains followed a similar pattern during the first $6 \mathrm{~h}$, but after that point growth stopped for the depleted strain (Fig. 1b). When observed under the microscope a strong phenotype was seen from the first time point $(t=3 \mathrm{~h}$ ), with elongated cells (Fig. $1 \mathrm{c}, \mathrm{d})$. At later time points branching was also seen, which corresponds to the formation of new poles at misplaced sites over the lateral walls of the bacterial cell and is a recurrent phenotype of mycobacterial cell division defects ${ }^{29}$ or of $E$. coli cells with a misplaced peptidoglycan machinery ${ }^{30,31}$. At later points of the time course $(t=$ $12 \mathrm{~h}$ or overnight cultures) cell lysis was frequently observed. This sepF depletion phenotype was rescued when the strain was complemented with a plasmid carrying an extra copy of sepF under the control of the $P_{\text {tet }}$ promoter (Supplementary Fig. 1), thus demonstrating the essentiality of sepF in C. glutamicum.

Using the fluorescent $\mathrm{D}$-ala-D-ala analog $\left(\mathrm{HADA}^{32}\right)$ to label newly incorporated peptidoglycan (PG), we showed that SepF depletion did not affect polar elongation (Fig. $1 \mathrm{c}$ and Supplementary Fig. 2). However, PG incorporation at mid-cell was lost and the cells were unable to form septa, thus showing that SepF is an essential component of the divisome in Corynebacteria. This absence of septa is clearly different from the SepF depletion phenotype in B. subtilis, where septa were present but largely deformed ${ }^{19}$, suggesting that SepF homologs might have evolved different functions linked to the presence or absence of other auxiliary proteins such as FtsA. A phylogenetic analysis of bacterial SepF homologs shows that the proteins from Firmicutes and Actinobacteria do indeed fall into two clearly distinct groups (Supplementary Fig. 3) and suggests vertical inheritance with no horizontal transfer between both phyla. Interestingly, detectable FtsA homologs could not be identified in Actinobacteria nor in Cyanobacteria or some early-branching Firmicutes, which-together with the presence of SepF-like proteins (but not FtsA) in some archaeal lineages-would suggest an ancestral role for SepF in cell division.

Above we showed that septal PG synthesis was impaired in the absence of SepF, indicating that the cells could no longer assemble a functional divisome at mid-cell. As the Z-ring precedes septum formation, we asked what happened to Fts $Z$ localization during depletion. We introduced mNeon-FtsZ as a dilute label under the control of $P_{g n t K}$, a tight promoter that is repressed by sucrose and induced by gluconate ${ }^{33}$ (Supplementary Fig. $4 \mathrm{a}, \mathrm{b}$ ). The minimal leakage of this promoter in sucrose was sufficient to give a signal for mNeon-FtsZ without affecting the phenotype, which remained wild-type-like (Supplementary Fig. 4c) and with a phenotype during SepF depletion comparable to that of the $P_{\text {ino- }}$ sepF strain (Supplementary Fig. 5). mNeonFtsZ was followed every $3 \mathrm{~h}$ during the depletion of SepF. As expected, $\mathrm{mNeon}$-FtsZ localized to mid-cell at time point 0 , when SepF was still present, in a typical "Z-ring" (Fig. 1e and Supplementary Fig. 5). From the following time point at $3 \mathrm{~h}$, mNeon-FtsZ was completely delocalized into foci (possibly representing short filament structures) all over the cell, showing that SepF is indeed necessary for bringing FtsZ to the membrane to form a unique and functional Z-ring. Interestingly at $6 \mathrm{~h}$ the distribution of mNeon-FtsZ, although lost at mid-cell, appears to be clustered and not randomly distributed throughout the cell (Fig. 1f). This observation points to an as yet undiscovered FtsZ 
a

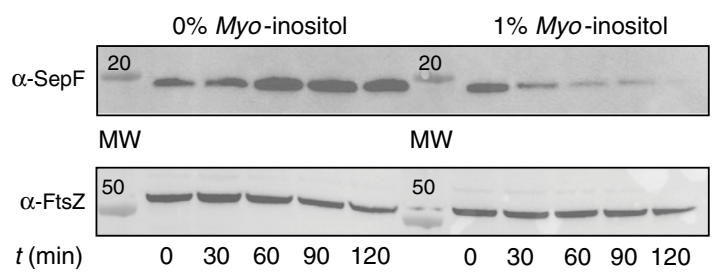

b

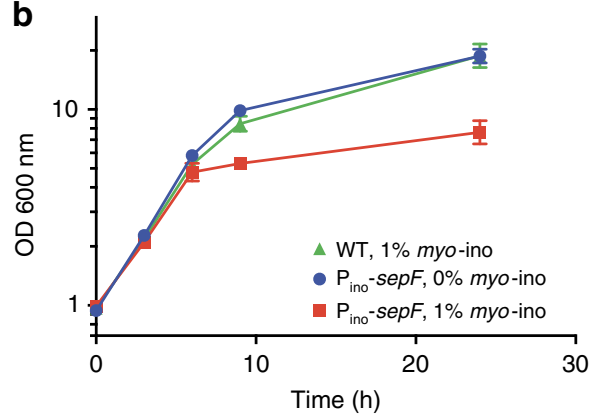

C
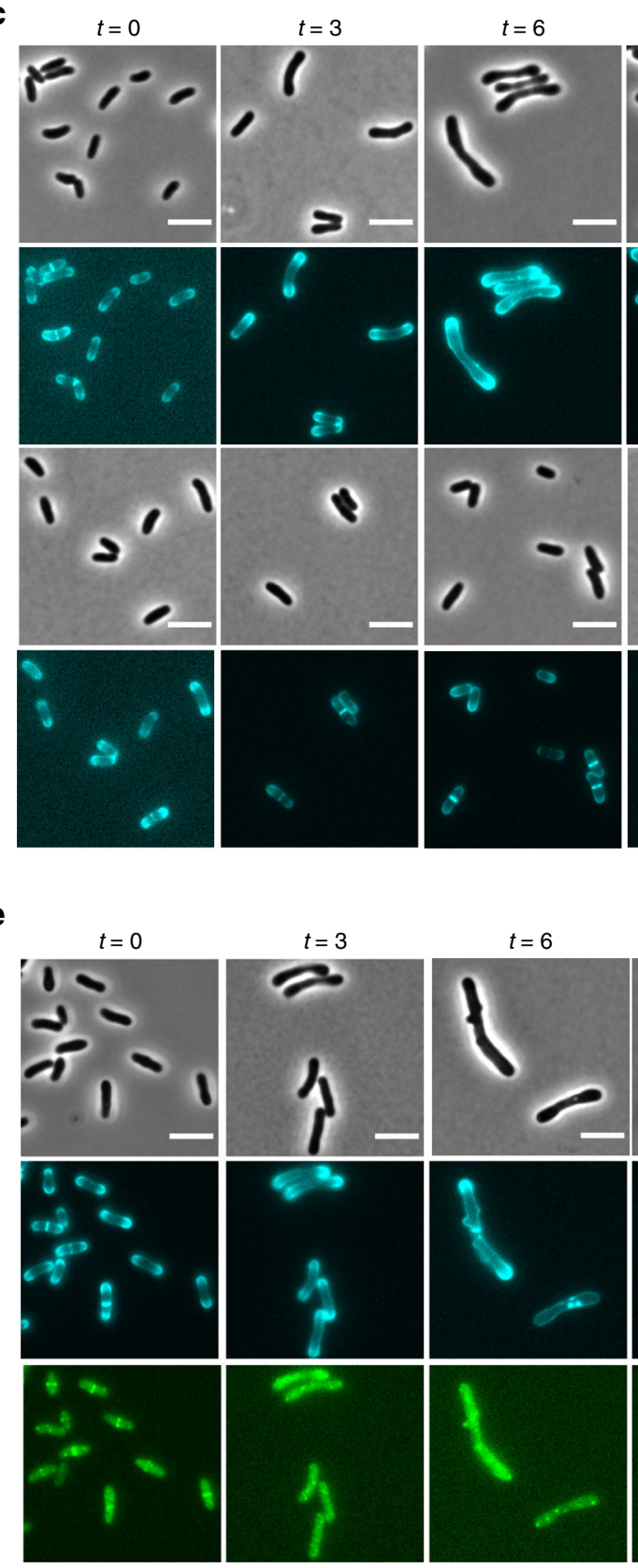

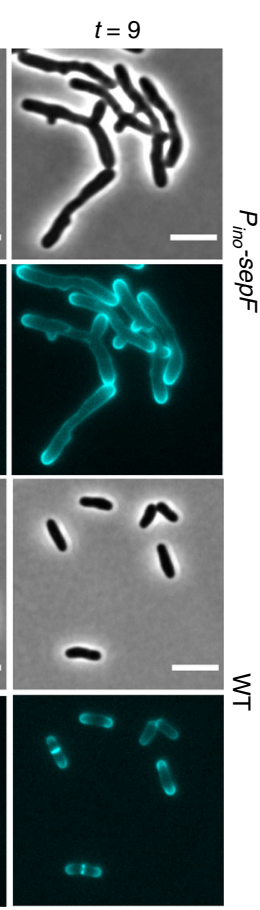

d 16
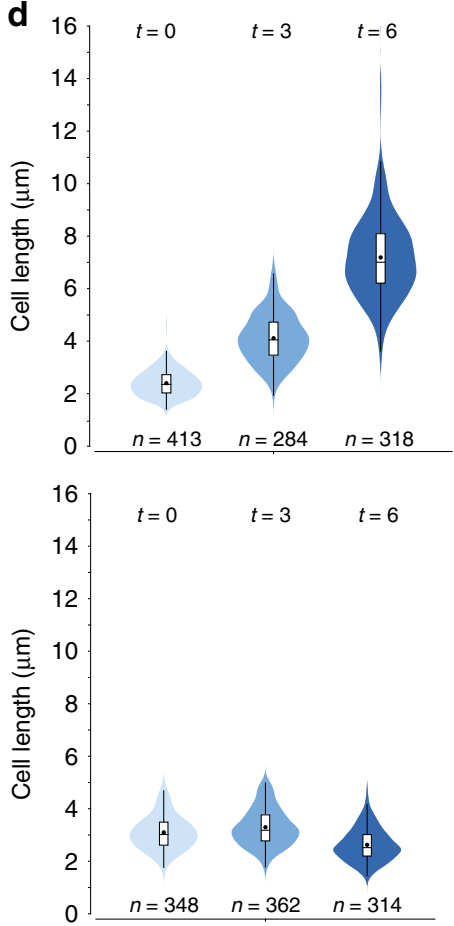

f

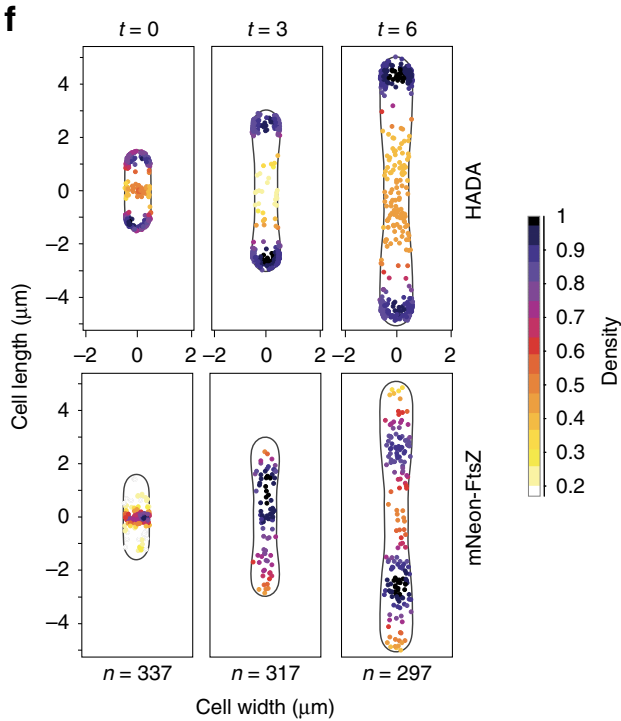

spatial regulation mechanism, since the well characterized nuclear occlusion and Min systems in E. coli and B. subtilis are absent in Actinobacteria $^{16}$. Altogether these data show that in the absence of SepF, FtsZ cannot assemble at mid-cell anymore and is delocalized in the cell in a non-random manner.
Molecular details of SepF interactions. To understand the mechanisms by which SepF participates in early divisome assembly we set out to characterize the molecular details of the interaction of SepF with both the membrane and FtsZ. The molecular organization of SepF is highly conserved and, like FtsA 
Fig. 1 Phenotypic characterization of $\boldsymbol{P}_{\text {ino }}$-sepF. a SepF depletion. Western blots of whole-cell extracts from the $P_{\text {ino }}$-sepF strain, in the absence (not depleted) or presence (SepF depleted) of $1 \%$ myo-inositol during $2 \mathrm{~h}$. SepF and FtsZ levels were revealed using anti-SepF ( $\alpha$-SepF) and anti-FtsZ ( $\alpha$-FtsZ)

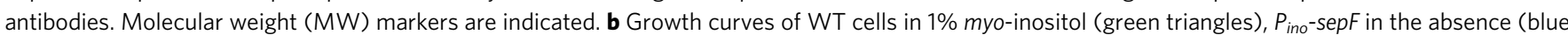
circles) or presence (red squares) of $1 \%$ myo-inositol. Error bars represent the mean \pm SD. c Representative images in phase contrast (upper row) and

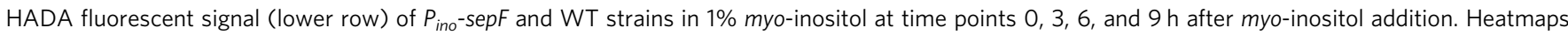
representing the localization pattern of HADA at 0,3 , and $6 \mathrm{~h}$ are shown in Supplementary Fig. 2a; d Violin plot showing the distribution of cell length at time points $0,3,6 \mathrm{~h}$ after myo-inositol addition for $P_{\text {ino }}$-sepF (top) and WT (bottom) from $\mathbf{c}$. The number of cells used in the analyses ( $n$ ) is indicated below each violin representation, triplicate analyses and statistics are shown in Supplementary Fig. $2 \mathrm{~b}$ and Supplementary Tables 5 and 6 . The box indicates the 25th to the 75th percentile and the whiskers indicate the 95\% confidence interval. The mean and the median are indicated with a dot and a line in the box, respectively. e Representative images in phase contrast (upper row), HADA fluorescent signal (middle row) and mNeon-FtsZ fluorescent signal (bottom row) at time points $0,3,6$, and $9 \mathrm{~h}$ after myo-inositol addition for cells grown in minimal medium CGXII supplemented with $4 \%$ sucrose. $\mathbf{f}$ Heatmaps representing the localization pattern of HADA and $\mathrm{mNeon}$-Fts $\mathrm{Z}$ at 0,3 , and $6 \mathrm{~h}$. $n$ numbers represent the number of cells used in the analyses. Triplicate analyses for the distribution of cell length at time points $0,3,6 \mathrm{~h}$, as well as heatmaps for fluorescence distribution are shown in Supplementary Fig. 5 . Scale Bars are $5 \mu \mathrm{m}$. Source data are provided as a Source Data file. The data shown are representative of experiments made independently in triplicate.

or ZipA, the protein contains an intrinsically disordered linker (L) of about 50 residues that separates the putative membranebinding peptide $(\mathrm{M})$ at the $\mathrm{N}$-terminus from the FtsZ-binding core domain $(\mathrm{C})$ at the $\mathrm{C}$-terminus ${ }^{11,20}$ (Fig. 2a). We proved that the predicted amphipathic helix at the N-terminus of C. glutamicum SepF did interact with lipid membranes (Supplementary Fig. 6a-c). Using tryptophan fluorescence titration, the peptide corresponding to the first 14 amino acids of SepF $\left(\operatorname{SepF}_{\mathrm{M}}\right)$ was shown to bind small unilamellar vesicles (SUVs) with a $\mathrm{Kd}$ of $32(+/-2) \mu \mathrm{M}$. In far-ultraviolet (UV) circular dichroism the $\mathrm{SepF}_{\mathrm{M}}$ peptide in solution behaved as a random coil and only folded into an a-helix upon interaction with SUVs, a behavior similar to that seen for B. subtilis SepF ${ }^{11}$.

To elucidate the structural basis of FtsZ recognition, we crystallized the SepF C-terminal core domain $\left(\operatorname{SepF}_{\Delta M L}\right)$ in complex with a 10-residues peptide comprising the conserved

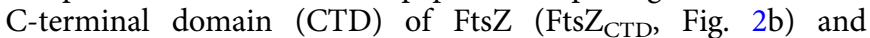
determined the crystal structure at $1.6 \AA$ resolution (Supplementary Table 1). The SepF structure revealed a symmetric homodimer, with monomers that contain a central fourstranded $\beta$-sheet stacked against two $\alpha$-helices $(\alpha 1, \alpha 2)$ involved in dimerization and capped by a C-terminal $\alpha$-helix ( $\alpha 3)$ on the opposite side of the sheet (Fig. 2c). The homodimer contains two identical $\mathrm{FtsZ}_{\mathrm{CTD}}$-binding pockets, each made up of residues coming from both protomers (Fig. 2d), defining a dimeric functional unit for the SepF-FtsZ interaction. This 2:2 binding stoichiometry can explain mechanistically why B. subtilis SepF has a bundling effect on FtsZ protofilaments ${ }^{34}$. Corynebacterial SepF has a similar capability, as shown by FtsZ polymerization assays at different SepF concentrations (Fig. 2e). Even at substoichiometric amounts of full-length SepF, the data showed an immediate influence on polymerization dynamics and a strong FtsZ bundling effect. Comparable changes on FtsZ polymerization were also observed for the C-terminal core alone $\left(\operatorname{SepF}_{\Delta \mathrm{ML}}\right)$ but not for a SepF double mutant $\left(\operatorname{SepF}_{\mathrm{K} 125 \mathrm{E} / \mathrm{F} 131 \mathrm{~A}}\right.$, see below) that is unable to bind FtsZ (Supplementary Fig. 7a, b), excluding the possibility that the light scattering signal could result from SepF polymerization alone. Furthermore, visualization of the protein mixture by negative stain electron microscopy (EM) after 10 min of incubation clearly showed thick bundles of FtsZ protofilaments, as well as highly curved filaments (Fig. 2f). Filaments and bundles were not observed in the absence of nucleotide or with SepF alone. Moreover, GTP and the slowly hydrolyzable analog GMPCPP produced a similar FtsZ bundling behavior, suggesting that GTP hydrolysis is not required for bundling (Supplementary Fig. 7c). We also showed that SepF did not significantly affect the GTPase activity of FtsZ (Supplementary Fig. $7 \mathrm{~d}$ ), in agreement with previous results on $B$. subtilis $\mathrm{SepF}^{22}$.
The bound Fts $Z_{\text {CTD }}$ is clearly visible in the electron density map (Supplementary Fig. 8a), and adopts a hook-like extended conformation that fits into a mostly hydrophobic binding pocket formed by conserved SepF residues, where it is further stabilized by additional intermolecular hydrogen-bonding interactions (Fig. 2d and Supplementary Fig. 8b). The apparent Kd value for the $\operatorname{SepF}_{\Delta \mathrm{ML}}-\mathrm{FtsZ}_{\mathrm{CTD}}$ interaction, as determined by surface plasmon resonance (SPR), was $15 \mu \mathrm{M}(+/-1 \mu \mathrm{M})$ (Supplementary Fig. 9), a value that is in the same range as those previously

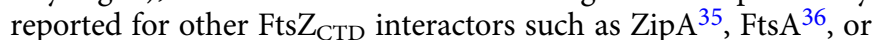
$\mathrm{ZapD}^{37}$. The interface was further validated by mutating two

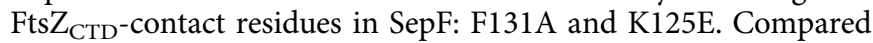
with the wild-type protein, the single mutant $\operatorname{SepF}_{\triangle \mathrm{ML}, \mathrm{F} 131 \mathrm{~A}}$ was greatly compromised for FtsZ binding (apparent $\mathrm{Kd}=340+1-$ $47 \mu \mathrm{M})$, whereas the double mutant $\operatorname{SepF}_{\Delta \mathrm{ML}, \mathrm{K} 125 \mathrm{E} / \mathrm{F} 131 \mathrm{~A}}$ exhibited no detectable binding in the range of protein-peptide concentrations tested (Fig. 2g and Supplementary Fig. 9).

Most FtsZ-binding proteins that have been characterized to date recognize the $\mathrm{Fts}_{\mathrm{CTD}}$, which represents a "landing pad" for FtsZ interactors ${ }^{38}$. Other known structures of regulatory proteins in complex with Fts $Z_{\mathrm{CTD}}$ include T. maritima FtsA and the E. coli proteins ZipA, SlmA and ZapD ${ }^{35-37,39}$. These crystal structures had shown that the Fts $Z_{\text {CTD }}$ peptide can adopt multiple conformations depending on its binding partner, from full- or partial-helical states as in the FtsA or ZipA complexes to distinct extended conformations as in ZapD or SlmA. The SepF-bound structure of the Fts $\mathrm{Z}_{\mathrm{CTD}}$ peptide revealed yet another non-helical conformation, reflecting the large conformational space that this small, highly conserved sequence can adopt in different biological contexts. It is interesting to note that SImA and SepF, despite their different structures and binding pockets, interact with the same highly conserved hydrophobic motif of the Fts $Z_{C T D}$ (Supplementary Fig. 10).

Membrane and FtsZ binding in vivo. To further evaluate the physiological roles of SepF-membrane and SepF-FtsZ interactions we constructed fluorescently tagged SepF constructs that were either unable to bind the lipid membrane ( $\operatorname{SepF}_{\Delta \mathrm{ML}}$-Scarlet) or impaired for FtsZ binding $\left(\mathrm{SepF}_{\mathrm{K} 125 \mathrm{E} / \mathrm{F} 131 \mathrm{~A}}-\mathrm{Scarlet}\right)$. When SepF-Scarlet was overexpressed under the control of the $P_{\text {gnt } K}$ promoter, it complemented the SepF depletion strain for growth (Fig. 3a, b and Supplementary Fig. 11). It should be noted, however, that the cells were more elongated than control cells, indicating that the C-terminal fusion does affect the function of SepF to some extent. In contrast, both $\operatorname{SepF}_{\Delta \mathrm{ML}}-\mathrm{Scarlet}$ and SepF $F_{\mathrm{K} 125 \mathrm{E} / \mathrm{F} 131 \mathrm{~A}}$-Scarlet completely failed to complement the strains and showed distinct localization patterns (Fig. 3c). Upon removal of the membrane-binding and linker domains, the $\operatorname{SepF}_{\Delta \mathrm{ML}}-$ Scarlet construct was observed to form distinct foci of 

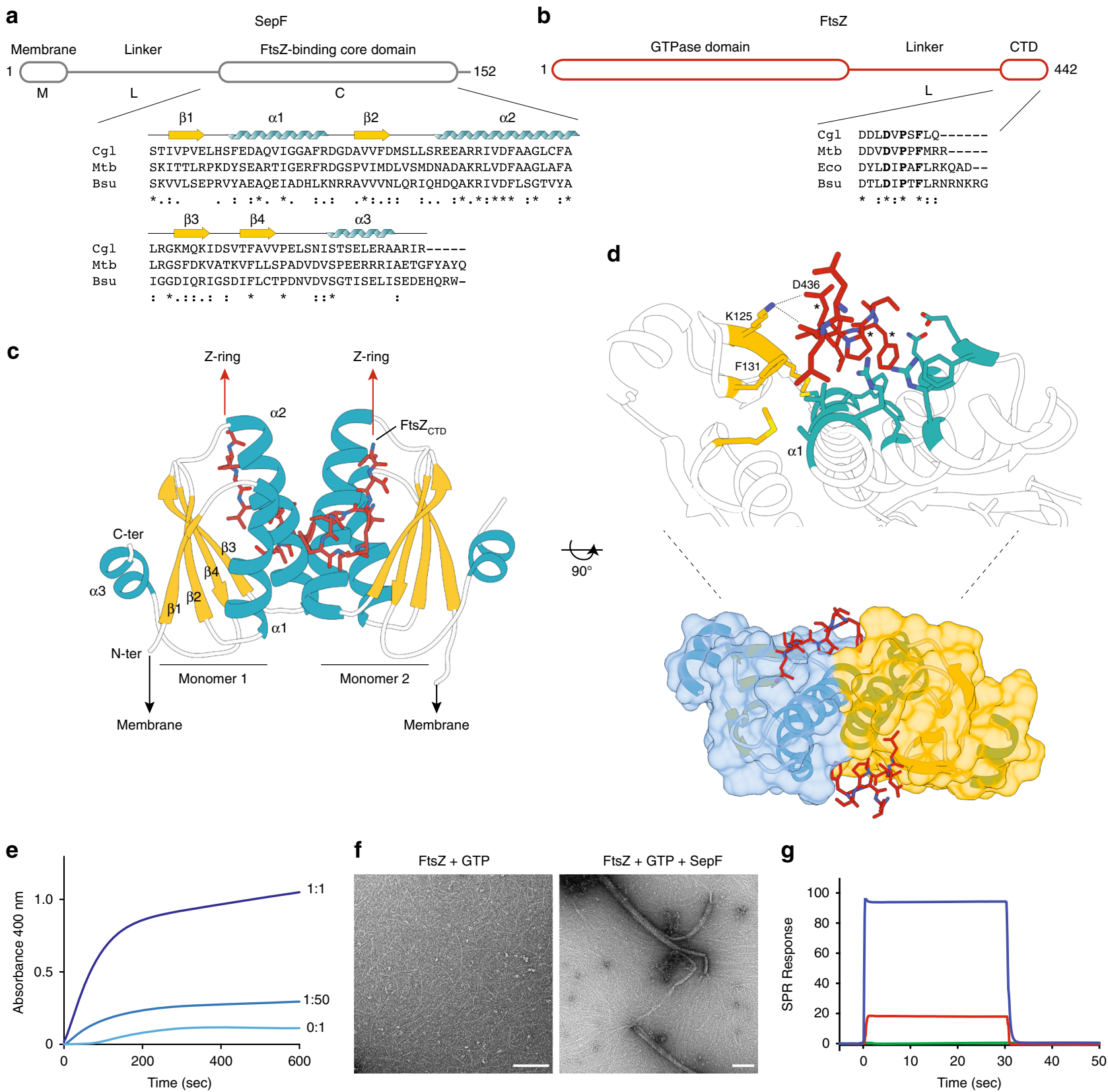

Fig. 2 Molecular characterization of the SepF-FtsZ interaction. a Schematic outline of SepF domains and sequence alignment of selected SepF homologs ( Cgl, C. glutamicum; Mtb, M. tuberculosis; Bsu, B. subtilis). Secondary structure elements are shown above the sequences. b Schematic outline of FtsZ domains and $\mathrm{Fts}_{\mathrm{CTD}}$ sequence alignment of selected homologs $\left(\mathrm{EcO}, \mathrm{E}\right.$. coli). Asterisks ${ }^{\star}{ }^{\star}$ ) indicate strictly conserved positions in the alignment and residues involved in SepF binding are shown in bold. $\mathbf{c}$ Crystal structure of the SepF dimer in complex with two Fts $Z_{\text {CTD }}$ peptides. The orientations of the $\mathrm{N}$ and C- termini of SepF and FtsZ are compatible with membrane binding on one hand and Z-ring formation on the other. $\mathbf{d}$ Detailed view of the FtsZ-binding pocket in SepF showing residues involved in protein-protein interactions (see Supplementary Fig. 8 for details). Conserved Fts $Z_{\text {CTD }}$ residues $D_{436}, P_{438}$, and $\mathrm{F}_{440}$ are labeled $\left(^{\star}\right)$, and SepF residues $\mathrm{K} 125$ and F131 were those mutated to abolish FtsZ binding. e FtsZ polymerization in the presence of varying levels of SepF. The stoichiometric SepF:FtsZ ratios are indicated for each curve. $\mathbf{f}$ Negatively stained EM micrographs of FtsZ filaments in the absence (left) and presence (right) of SepF. The polymers in the left-hand panel have a width of about $4 \mathrm{~nm}$, which corresponds to the width of FtsZ. The bundles shown in the right-hand panel range in width from $20-60 \mathrm{~nm}$. Scale bars are $150 \mathrm{~nm}$. The data shown are representative of experiments made independently in triplicate. $\mathbf{g}$ SPR responses in resonance units $(\mathrm{RU})$ for $200 \mu \mathrm{M}$ Fts $Z_{\mathrm{CTD}}$ interacting with immobilized SepF (blue), SepF $\mathrm{F}_{\mathrm{F} 131 \mathrm{~A}}(\mathrm{red})$, and SepF $\mathrm{F}_{\mathrm{K} 125 \mathrm{E} / \mathrm{F} 131 \mathrm{~A}}$ (green). The detailed SPR results are shown in Supplementary Fig. 9. Source data are provided as a Source Data file.

SepF, similar to those seen for mNeon-FtsZ. This deletion mutant of SepF can still bind and bundle FtsZ as shown above but has lost the capacity to find the mid-cell and go to the membrane (Fig. 3c).

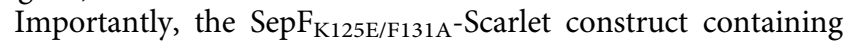
the mutations that abolish FtsZ interaction was diffuse in the cytoplasm, showing that FtsZ binding is needed for membrane attachment even though the protein contains the N-terminal amphipatic helix. This suggests that, although the N-terminal peptide of SepF can bind membranes by itself (Supplementary Fig. 6), it would be unable to direct a protein monomer to the membrane. To confirm this hypothesis, we constructed a 
a

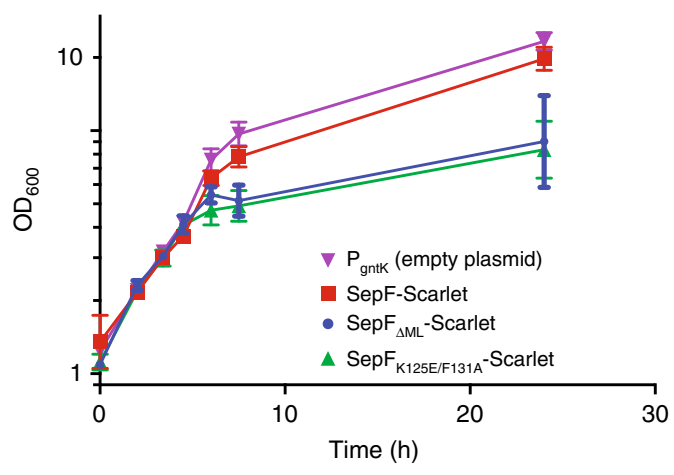

b

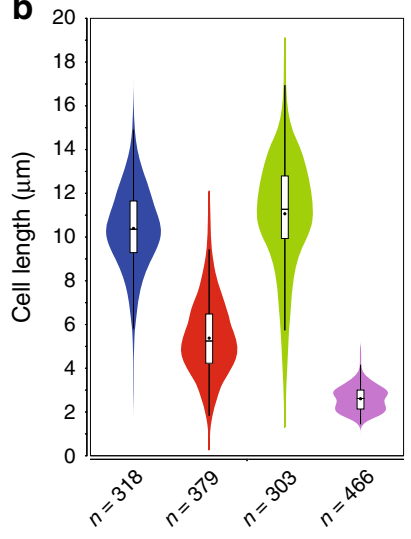

C

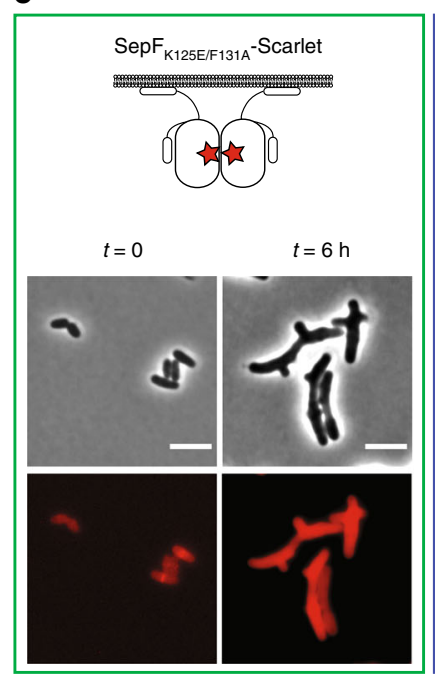

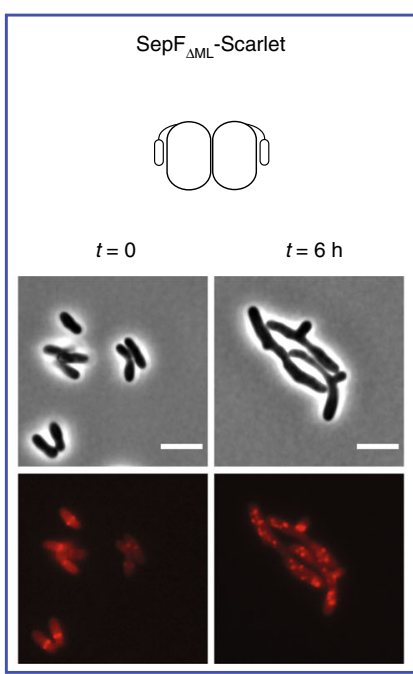

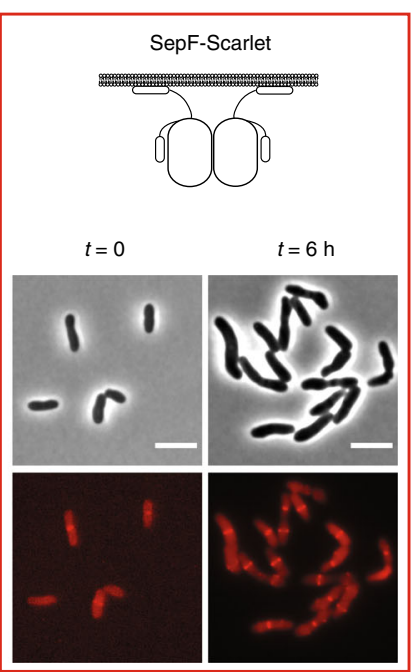

Fig. 3 Complementation and localization of SepF mutants in the $\boldsymbol{P}_{\text {ino }}$-sepF strain. a Growth curves of SepF-Scarlet (red), SepF ${ }_{\triangle M L}-S_{C} a r l e t$ (blue),

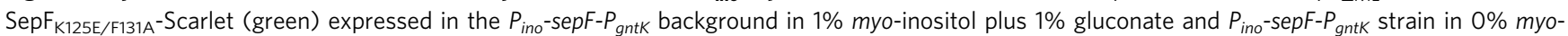
inositol plus $1 \%$ gluconate (purple). Error bars represent the mean \pm SD. b Violin plot showing the distribution of cell length at time point $6 \mathrm{~h}$ after myoinositol and gluconate addition for the strains corresponding to the growth curve (same color code). The number of cells used in the analyses ( $n$ ) is indicated below each violin representation. The box indicates the 25 th to the 75 th percentile and the whiskers indicate the $95 \%$ confidence interval. The mean and the median are indicated with a dot and a line in the box, respectively. c Representative images in phase contrast (upper row) and Scarlet fluorescent signal (lower row) of the complemented strains of $\mathbf{a} . t=0$ corresponds to the strains before depletion by myo-inositol and induction of exogenous $P_{\text {gntK }}$ controlled constructs by gluconate. Western blots of whole-cell extracts from the above strains during depletion, as well as triplicate analyses for the distribution of cell length at time points $6 \mathrm{~h}$ are shown in Supplementary Fig. 11. The data shown are representative of experiments made independently in triplicate. Scale bars $=5 \mu \mathrm{m}$. Source data are provided as a Source Data file.

fusion protein in which the membrane-binding and linker regions of SepF (residues 1-63) were fused to the monomeric protein Scarlet. We found that this construct remained cytoplasmic when overexpressed in C. glutamicum (Supplementary Fig. 12), confirming that a higher avidity (such as that provided by FtsZ filaments decorated with multiple SepF dimers) may be needed for membrane tethering. Our results are consistent with previous work showing that SepF from $M$. smegmatis was dependent on FtsZ for localization at the Z-ring ${ }^{20}$, indicating that a dynamic interplay between the two proteins is required for membrane association and Z-ring formation, and that SepF needs to act in the early actinobacterial divisome. This is also reminiscent of FtsA from $E$. coli, which requires FtsZ for localization at the septum ${ }^{40}$, although FtsA can go to the membrane by itself ${ }^{8}$. Taken together, the above results demonstrate that SepF and FtsZ are intimately linked and interdependent to form a functional Z-ring and a viable cell in Actinobacteria.
A putative mechanism for SepF polymerization. The crystal structure of the globular core of SepF reported in this work differs from the available structures of other bacterial ( $\mathrm{pdb}$ codes 3P04, 3ZIE) and archaeal (3ZIG, 3ZIH) SepF-like homologs in that it contains an additional helix ( $\alpha 3$ ) at its C-terminus (Fig. 2c). This helix was predicted but not seen in other bacterial homologs because it is either missing in the construct or structurally disordered in the crystal ${ }^{11}$. Helix $\alpha 3$ formation and stabilization were not due to FtsZ binding, because the crystal structure of unliganded $\operatorname{SepF}_{\Delta \mathrm{ML}}$ (Supplementary Table 1) revealed the same overall structure than FtsZ $\mathrm{CTD}_{\text {-bound }} \mathrm{SepF}_{\Delta \mathrm{ML}}$ (rmsd of $0.83 \AA$ for 160 equivalent $\mathrm{Ca}$ atoms in the homodimer), indicating that peptide binding produced no significant conformational changes. The presence of this helix has important functional implications as it caps the $\beta$-sheet (Fig. $4 \mathrm{a}$ ) that was previously described as the dimerization interface of $B$. subtilis SepF $F^{11}$. In fact, the crystal structure of the latter revealed two possible dimerization interfaces: one that occurred via the central $\beta$-sheet, which was 
a

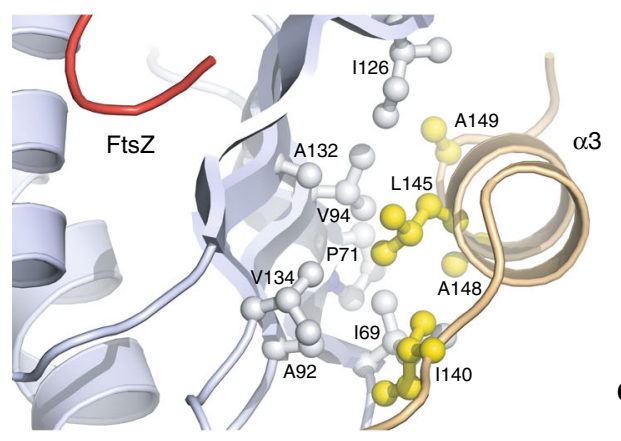

b

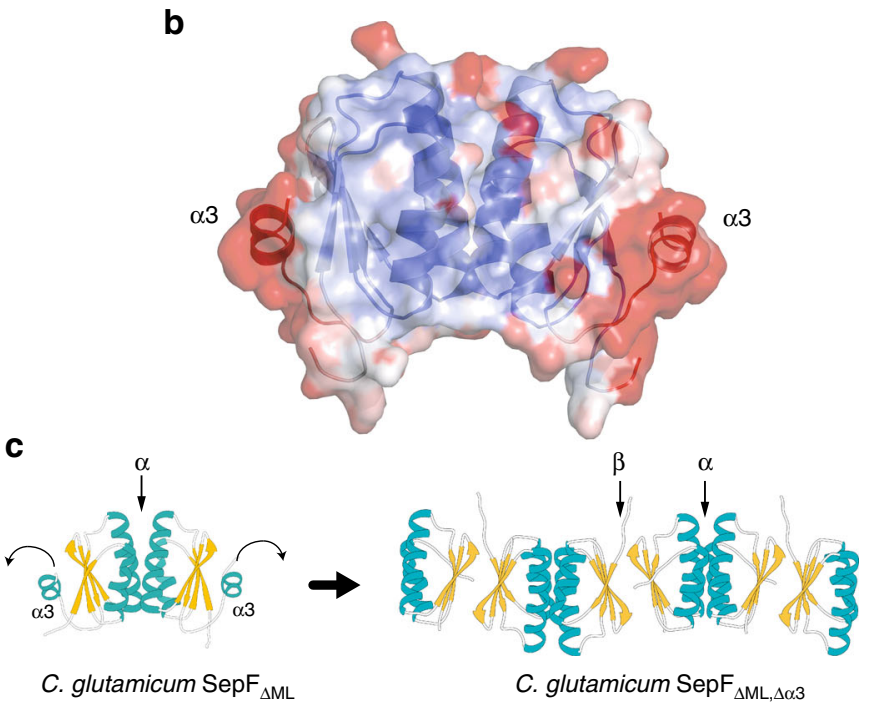

C

Fig. 4 Putative regulatory role of helix $\boldsymbol{\alpha} \mathbf{3}$. a Hydrophobic interactions mediate the association of the C-terminal helix $\alpha 3$ (yellow) with the central $\beta$-sheet (gray) in the SepF protomer. b Overall structure of the unliganded SepF ${ }_{\Delta M L}$ homodimer color coded according to temperature factors, from blue (lowest values) to red (highest values). c Deletion of helix $\alpha 3$ in $\operatorname{SepF}_{\Delta M L, \Delta \alpha 3}$ promotes the tight interaction between opposite $\beta$-sheets from different SepF dimers, leading to the formation of linear SepF polymers (see also Supplementary Fig. 13).

proposed to define the functional unit, and one that occurred via a 4-helix bundle, thought to be involved in protein oligomerization and ring formation ${ }^{11}$ (Supplementary Fig. 13a). Our crystal structure superimposed well with the 4-helix bundle-mediated SepF dimers from B. subtilis, supporting the hypothesis that the C. glutamicum SepF homodimer (Fig. 2c) is conserved across different bacterial species.

If the functional SepF unit is conserved, the $\beta$-sheet-mediated interface observed in B. subtilis SepF crystals could therefore mediate protein polymerization in solution. This interface, which was also seen in SepF-like proteins from Pyrococcus furiosus and Archaeoglobus fulgidus ${ }^{11}$, is precluded in the C. glutamicum SepF structure by the presence of the C-terminal helix a3 (Fig. 4a). However, inspection of the unliganded $\operatorname{SepF}_{\Delta \mathrm{ML}}$ structure revealed that this helix displays considerably higher B-factor values than the rest of the protein (Fig. $4 \mathrm{~b}$ ) and a similar trend is also observed in the $\mathrm{SepF}_{\triangle \mathrm{ML}}-\mathrm{FtsZ}_{\mathrm{CTD}}$ complex, suggesting that helix $\alpha 3$ could play a regulatory role on SepF polymerization by uncovering the outer face of the $\beta$-sheet for intermolecular interactions. To further investigate this hypothesis, we removed the helix and crystallized the resulting $\operatorname{SepF}_{\Delta \mathrm{ML}, \Delta \alpha 3}$ construct alone and in complex with FtsZ $\mathrm{CTD}_{\mathrm{CT}}$ (Supplementary Table 1). Despite a different crystal packing, the two structures did show a dimer-dimer association mediated by the opposing $\beta$-sheets in the crystal, generating linear SepF polymers similar to those observed for the B. subtilis homolog (Fig. 4c and Supplementary Fig. 13). These observations demonstrate that the $\beta$-sheet is indeed prone to self-interaction in solution and suggest that the amphipathic helix a3 might regulate SepF polymerization. It is interesting to note, however, that the anti-parallel orientation of the interacting $\beta$-sheets in three crystal forms of C. glutamicum SepF (Supplementary Fig. 13), although identical to each other, differs from the parallel orientation seen in the B. subtilis SepF structure, thus pointing to possible species-specific polymerization mechanisms.

The above polymerization model can account for the formation of SepF rings in $B$. subtilis ${ }^{22}$. In our hands, C. glutamicum SepF devoid of helix a3 (i.e., with the $\beta$-sheet accessible for protein-protein interactions) remained dimeric in solution and we were unable to detect higher order assemblies by size exclusion chromatography or analytical ultracentrifugation (Supplementary Fig. 14). Furthermore, we could observe regular rings of $\sim 40 \mathrm{~nm}$ diameter in negative stain EM for the related SepF homolog from M. tuberculosis (Supplementary Fig. 15), but our extensive attempts at detecting similar ring-like structures of C. glutamicum SepF were unsuccessful. For the latter, oligomerization may therefore require an increased local concentration, as found for instance in crystallization conditions or in a physiological situation linked to lipid membrane and/or FtsZ filament interactions, where avidity effects can push the equilibrium towards an oligomeric state. Taken together, the above biophysical data suggest that the C-terminal helix a 3 could regulate SepF polymerization by controlling $\beta$-sheet-mediated interactions during Z-ring formation and divisome assembly.

Reversible SepF oligomerization. We next investigated the effects of lipid membranes and FtsZ binding on SepF polymerization. We found that incubation of SepF with SUVs led to SepF concentration-dependent polymerization in turbidity assays (Fig. 5a and Supplementary Fig. 16) and to the formation of large structures in dynamic light scattering (DLS) experiments (Supplementary Fig. 17a-c). When we looked at the end-point of these reactions in negative stain EM the lipid vesicles were tubulated (Fig. 5a), indicating that the N-terminal amphipathic helix of SepF has the capability to induce membrane remodeling upon protein polymerization. Surprisingly this behavior was completely reversed when the $\mathrm{Fts}_{\mathrm{CTD}}$ peptide was added to the reaction (Fig. 5b and Supplementary Fig. 17d): SepF depolymerized, lipid vesicles recovered their initial size in DLS, and small regular vesicles with no tubulation were observed in electron micrographs. When the same experiment was carried out with $\operatorname{SepF}_{\Delta \alpha 3}$, lacking the regulatory C-terminal helix, polymerization and vesicle tubulation were also seen but could only be partially reversed after addition of the $\mathrm{Fts}_{\mathrm{CTD}}$ peptide (Supplementary Fig. 18). In summary, SepF is a dimeric protein prone to polymerize forming rings at high concentration. Membrane binding would then displace the equilibrium to favor SepF polymerization in a concentration-dependent manner, while FtsZ binding would do it in the opposite sense, towards depolymerization. 
a
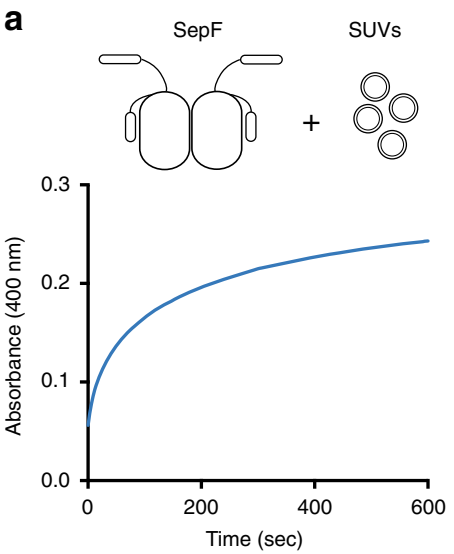

C

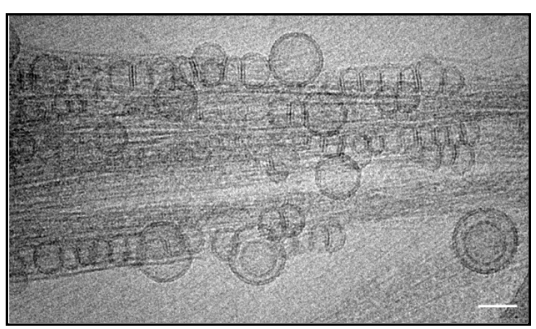

e
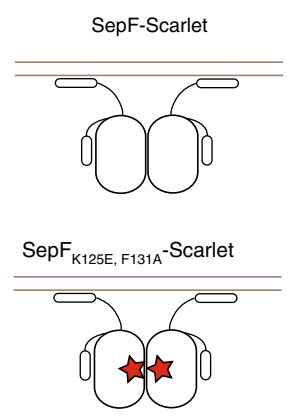

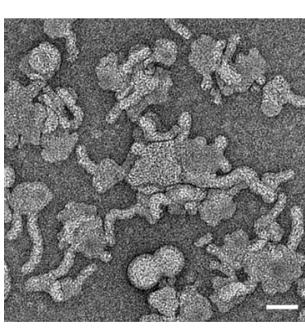

b
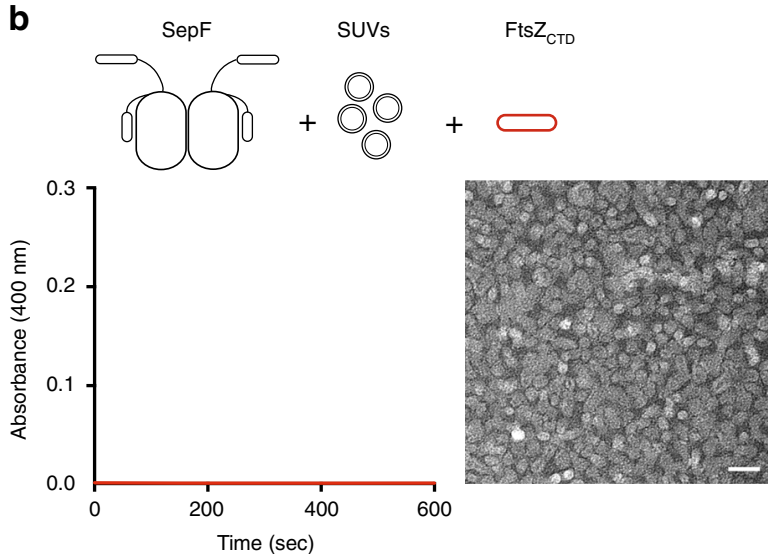

d
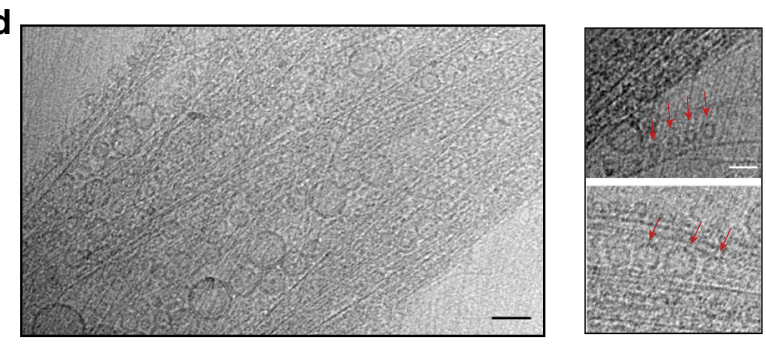

f

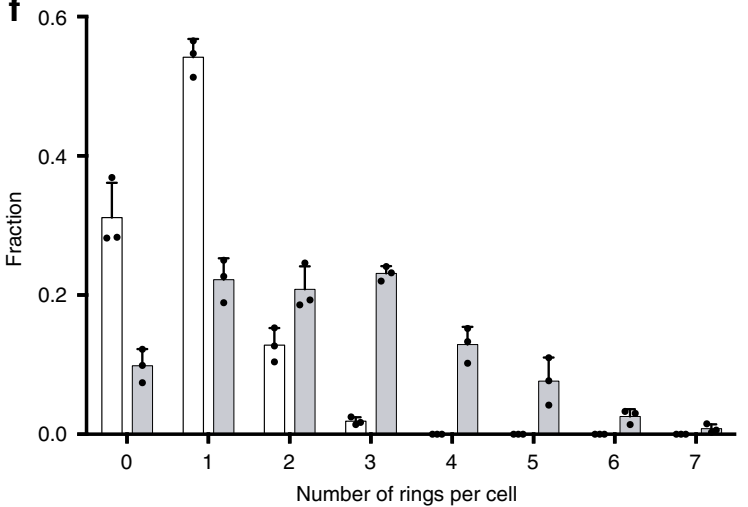

Fig. 5 SepF oligomerization upon lipid membrane-binding and reversal by FtsZ. a Polymerization assay and negatively stained EM images of the endpoint of the assay for SepF in the presence of SUVs. Scale bar: $50 \mathrm{~nm}$. b Idem for SepF in the presence of SUVs + FtsZ images of the ternary complex full-length FtsZ-GTP + SepF + SUVs. A bundle of FtsZ filaments is decorated by tubulated lipid vesicles, mostly found on the periphery of the bundles. The smaller panels show two examples of tubulated lipid vesicles, where black arrows indicate the putative SepF rings. Scale bars in large and small panels, respectively: 50 and $30 \mathrm{~nm}$. $\mathbf{d}$ In the central regions of the bundles, several small, non-tubulated, vesicles are in close contact with FtsZ filaments. Red arrows indicate a few examples of these vesicles in the right panels. Scale bars in large and small panels, respectively: 50 and 30 nm. e Phase contrast (left columns) and Scarlet fluorescent signal (right column) images show the phenotypic differences observed upon overexpression of

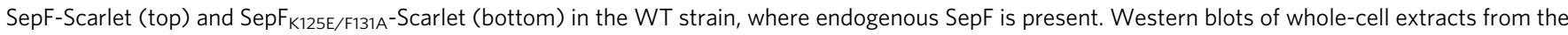
above strains as well as triplicate analyses for the distribution of cell length are shown in Supplementary Fig. 19. Scale bars $=5 \mu \mathrm{m}$. $\mathbf{f}$ Frequency histogram indicating the number of ring-like structures per cell for SepF-Scarlet (white) and SepF $F_{K 125 A / F 131 A}-S c a r l e t$ (gray). The frequencies were calculated from $n$

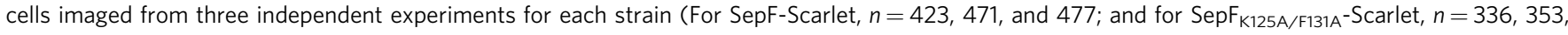
and 392). The bars, with data points overlapping, represent the mean \pm SD. Source data are provided as a Source Data file. All data shown are representative of experiments made independently in triplicate.

In cryo-EM experiments with full-length FtsZ (instead of $\mathrm{FtsZ}_{\mathrm{CTD}}$ ), we were able to trap an intermediate state of the ternary complex (lipid membranes, SepF, FtsZ-GTP). In the images (Fig. 5c) negatively charged lipid vesicles of different sizes are brought together by rings of SepF, forming tubular structures at the periphery of the bundles, in which the SepF rings involved do not interact with FtsZ filaments. On the other hand, both these peripheral tubular structures (Fig. 5c) as well as the individual smaller vesicles trapped at the central bundle regions (Fig. $5 \mathrm{~d}$ ) attach to and decorate the FtsZ filaments, demonstrating that the dimeric form of SepF retains lipid-binding capability. Taken together, these results point to a dynamic equilibrium between two SepF subpopulations, a dimeric form associated with FtsZ bundling and membrane tethering and a second polymeric form associated with membrane remodeling.

Further evidence for the interdependence of SepF and FtsZ dynamics in vivo was obtained by overexpressing

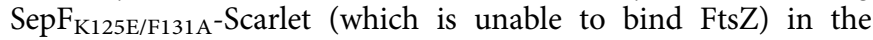
WT background. From mass spectrometry data (immunoprecipitation experiments coupled to crosslinking) we found that FtsZ 
a

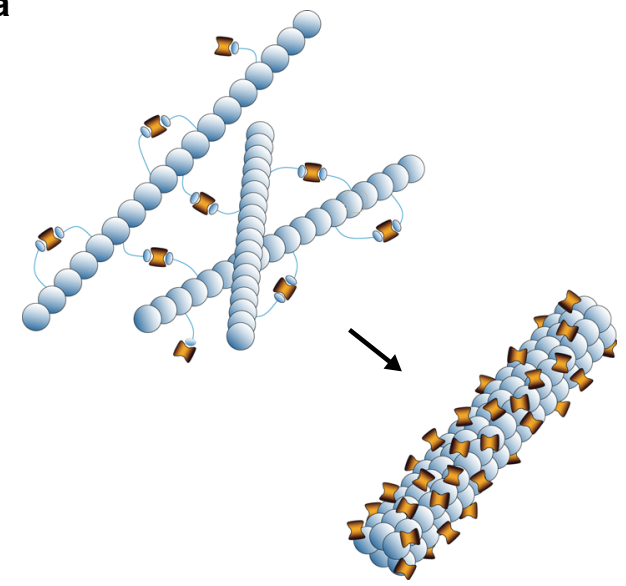

b
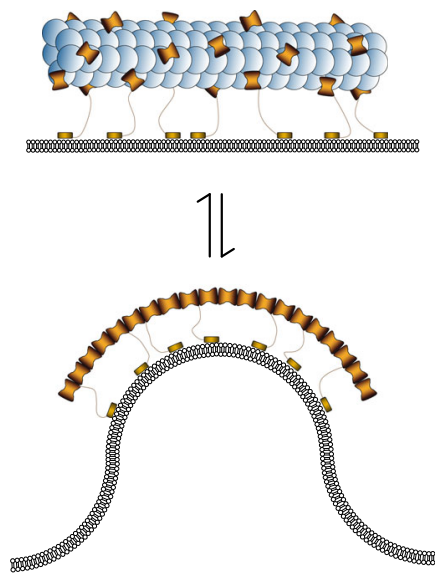

Fig. 6 Schematic model depicting the possible mode of action of SepF in the early stages of Z-ring assembly and septum formation. a Formation of the FtsZ-SepF complex in the cytoplasm leads to FtsZ filament bundling. b At the membrane, homodimeric SepF molecules bound to FtsZ filaments would sustain membrane tethering (top), while membrane-bound polymerized SepF would play an active role in remodeling the lipid bilayer for septum formation (bottom).

binding in the strain expressing SepF $_{\mathrm{K} 125 \mathrm{E} / \mathrm{F} 131 \mathrm{~A}}$-Scarlet was greatly reduced (7.2-fold; see Methods section and Supplementary Table 2) compared to SepF-Scarlet, but not abolished, showing that the mutant and endogenous SepF proteins interacted with each other. When we looked at the localization of SepF in these two strains, we observed a net increase in the number of ring-like structures per cell for $\mathrm{SepF}_{\mathrm{K} 125 \mathrm{E} / \mathrm{F} 131 \mathrm{~A}}$-Scarlet as opposed to mostly single rings at mid-cell for SepF-Scarlet (Fig. 5e, f and Supplementary Fig. 19). Thus, a corrupted FtsZ-binding site led to the formation of multiple, more stable SepF rings that contain not only fully functional endogenous SepF but also non-

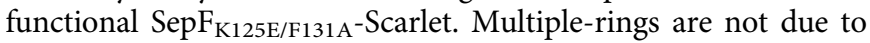
protein overexpression or to the presence of a fluorescent tag, because the multiple-rings phenotype is not observed for cells overexpressing wild-type SepF under the control of the strong $P_{t a c}$ promoter ( 30-fold protein overexpression upon induction), nor for cells in which the Scarlet tag was fused to the genomic copy of $s e p F$ under the control of its endogenous promoter (Supplemen-

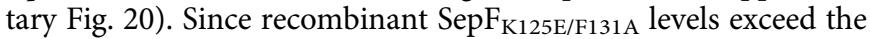
endogenous protein levels (Supplementary Fig. 19), these partially functional rings are expected to contain patches that cannot bind and stabilize FtsZ filaments. This would in turn interfere with the formation of a fully dynamic oligomeric Z-ring structure, which requires correct alignment and stabilization for solid treadmilling-driven assembly of the division machinery $10,41,42$.

\section{Discussion}

Here, we demonstrated that SepF and FtsZ are interdependent to form a functional Z-ring and that SepF is essential in C. glutamicum. Our structural data revealed the FtsZ-binding pocket, defining the SepF homodimer as the functional unit, and suggesting a reversible $\beta$-sheet-mediated oligomerization interface possibly regulated via an alpha helical switch. We found that FtsZ filaments and lipid membranes have opposing effects on SepF polymerization, pointing to a complex dynamic role of the protein at the division site, involving FtsZ bundling, Z-ring tethering and membrane reshaping activities that are needed for proper Z-ring assembly and function.

Our results put forward a mechanistic model for SepF function during the early stages of divisome assembly (Fig. 6). At cellular concentrations in the nanomolar range, unbound SepF dimers would neither bind to the membrane nor polymerize. A higher local SepF concentration would be achieved by FtsZ-GTP filament binding (Fig. 6a), which would in turn promote filament bundling (because of the 2:2 stoichiometry of the FtsZ:SepF complex), while precluding SepF polymerization. This initial process would result in cytoplasmic FtsZ filaments and bundles presumably decorated with most available SepF molecules in the cell, as the molar concentration of SepF in the cell is considerably lower (5-20-fold) than that of FtsZ (Supplementary Fig. 21). At the membrane, oligomeric and non-oligomeric (i.e., dimeric) forms of SepF would coexist, as suggested by the cryo-EM images of the ternary complex (Fig. 5c, d). For instance, some SepF molecules would remain in a dimeric form attached to the bundles, providing enough amphipathic peptides to sustain membrane tethering (Fig. 6b, top), while others would detach from the bundles to form membrane-bound polymers that will play an active role in remodeling the lipid bilayer for septum formation (Fig. 6b, bottom). Such redistribution is made possible by the highly dynamic nature of the FtsZ-SepF-membrane interactions and the opposite effects of competitive filament/membrane binding on SepF oligomerization. How the SepF-FtsZ complexes are specifically localized to the mid-cell and whether there are additional regulatory factors affecting the oligomerization state of SepF remains to be elucidated. These could be unidentified divisome components, or else post-translational modifications such as protein phosphorylation, known to play an important role in the regulation of actinobacterial cell division and morphogenesis ${ }^{43}$.

Protein dynamics are intrinsic functional features of tubulin (dynamic instability ${ }^{44}$ ) and FtsZ (treadmilling ${ }^{10}$ ). FtsZ by itself has the properties not only to self-organize and provide directionality, but also to deform lipids when a membrane-binding motif is attached to the protein ${ }^{45-47}$. In this case, Fts Z has been shown to assemble into dynamic vortices in vitro without the need for accessory proteins, but critically relying on concentration thresholds ${ }^{46}$. Concentration dependence is also true for accessory proteins such as the bundling protein $\mathrm{ZipA}^{48}$, or $\mathrm{ZapA}^{49}$ where the effect on FtsZ dynamics heavily relies on the protein concentrations used. In the bacterial cell FtsZ does not contain a membrane-binding domain and the self-assembly is counteracted by several parameters such as molecular crowding 50,51 , as well as spatial and temporary constraints for mid-cell localization. A functional tethering system thus needs to allow for accumulation of enough FtsZ molecules (i.e., via bundling) without trapping these bundles in static states. In E. coli, it was recently shown that the bundling protein ZapA increases FtsZ filament stability without affecting the treadmilling activity ${ }^{51}$. The Z-ring also 
needs to constantly adapt to the dynamics and shrinking of the membrane invagination during septal closure, and dynamic exchange is thus primordial to all FtsZ interacting systems.

Membrane remodeling activity has also been described for the E. coli membrane tether FtsA ${ }^{25}$. As FtsA and all other known FtsZ $_{\text {CTD }}$ interactors are absent from corynebacterial genomes, it is possible that SepF could play a more complex role in those organisms and contribute to both membrane tethering and remodeling. For SepF a plausible scenario could be that, during the early stages of assembly, polymerized FtsZ fragments are bundled and tethered to the membrane mainly by dimeric SepF, which-possibly assisted by auxiliary regulatory factors yet to be identified-would help FtsZ polymers to stabilize, find directionality, and start treadmilling to form a functional Z-ring. At the same time, this process would increase the local concentration of SepF at the membrane. Treadmilling would remove available Fts $\mathrm{Z}_{\mathrm{CTD}}$-binding sites, leading to $\mathrm{SepF}$ polymerization and membrane invagination, contributing to the net force required for cell constriction ${ }^{52}$. A possible consequence of this model is that SepF-induced septum formation would only occur when enough FtsZ has been accumulated at the membrane and treadmilling starts, making of SepF a checkpoint protein that would initiate constriction only once the cytomotive machinery is fully functional.

\section{Methods}

Bacterial strains and growth conditions. All bacterial strains used in this study are listed in the Supplementary Table 3. Escherichia coli DH5a or CopyCutter EPI400 were used for cloning and were grown in Luria-Bertani (LB) broth or agar plates at $37^{\circ} \mathrm{C}$ supplemented with $50 \mu \mathrm{g} / \mathrm{ml}$ kanamycin when required. For protein production, E. coli BL21 (DE3) was grown in LB or 2YT broth supplemented with $50 \mu \mathrm{g} / \mathrm{ml}$ kanamycin at the appropriate temperature for protein expression.

Corynebacterium glutamicum ATCC13032 was used as a wild-type (WT) strain. C. glutamicum was grown in brain heart infusion (BHI) at $30^{\circ} \mathrm{C}$ and $120 \mathrm{rpm}$ and was supplemented with $25 \mu \mathrm{g} / \mathrm{ml}$ kanamycin when required. When specified, minimal medium CGXII ${ }^{53}$ supplemented with sucrose, gluconate, IPTG, tetracycline, kanamycine and/or myo-inositol was used.

Cloning for recombinant protein production in $\mathbf{E}$. coli. The genes encoding for C. glutamicum sepF (cg2363), M. tuberculosis sepF (Rv2147c), and C. glutamicum $f t s Z$ (cg2366) were codon optimized and synthesized for E. coli protein production (Genscript) and used as templates for subsequent cloning. They were cloned into a pT7 vector containing an N-terminal 6xHis-SUMO tag. SepF mutants containing different domains: $\operatorname{SepF}_{\Delta \mathrm{ML}}$ (amino acids 63 to 152), $\operatorname{SepF}_{\Delta \mathrm{ML}, \Delta \alpha 3}$ (amino acids 63 to 137), $\operatorname{SepF}_{\Delta \alpha 3}$ (amino acids 1 to 137), $\operatorname{SepF}_{\Delta M L, F 131 A}, \operatorname{SepF}_{\Delta M L, K 125 E / F 131 A}$, $\mathrm{SepF}_{\mathrm{K} 125 \mathrm{E} / \mathrm{F} 131 \mathrm{~A}}$ and $M$. tuberculosis $\operatorname{SepF}_{\Delta \mathrm{ML}}\left(M t b S e p \mathrm{~F}_{\Delta \mathrm{ML}}\right.$, comprising amino acids 122 to 218 ) were constructed using either pairs of complementary primers carrying the desired deletion or point mutations on the primers listed in the Supplementary Table 4. PCR products were digested with DpnI and transformed into chimio-competent $E$. coli cells. All plasmids were verified by Sanger sequencing (Eurofins Genomics, France).

\section{Cloning for recombinant protein expression in C. glutamicum. For ectopic} recombinant expression of the different constructs in C. glutamicum, we used the synthetic pTGR5 shuttle expression vector under the control of the $P_{t a c}$ promoter, as well as two other expression vectors, pUMS_3 and pUMS_40, in which the $P_{t a c}$ promoter of pTGR5 was, respectively, exchanged by the promoters $P_{\text {gntK }}$ of $C$. glutamicum or $P_{\text {tet }}$ from pCLTON1 vector ${ }^{53-55}$ (Supplementary Table 3 ). FtsZ and SepF variants were assembled in these plasmids by either Gibson assembly or sitedirected mutagenesis using the primers listed in Supplementary Table 4. For cellular localization studies, $\mathrm{mScarlet}-\mathrm{I}^{56}$ was fused on the C-terminal side of SepF and mNeonGreen ${ }^{57}$ was fused on the $\mathrm{N}$-terminal side of FtsZ, including in both cases a flexible linker between the two fused proteins.

For co-expression of SepF and FtsZ, plasmid pUMS3-mNeon-cgFtsZ was digested with $\mathrm{XbaI}$ and SpeI and the fragment containing PgntK-mNeon-cgFtsZ was ligated in pTGR5-cgSepF plasmid previously digested with SpeI.

sepF conditional mutant and the sepFsscarlet strain. To obtain the conditional depletion of $\operatorname{sep} F$, the endogenous sepF was placed under the control of a repressible promoter. Using the two-step recombination strategy with the pk19mobsacB plasmid, we inserted the native promoter of the inositol phosphate synthase gene (ino1-cg3323), which can be repressed in the presence of myoinositol ${ }^{27}$. A terminator followed by the ino1 promoter was amplified by PCR from
pk19-P3323-lcp $A^{58}$. The $500 \mathrm{bp}$ up-stream region and down-stream region of sepf were amplified using chromosomal DNA of C. glutamicum ATCC13032 as a template. The different fragments were assembled in a pk19mobsacB backbone by Gibson assembly (NEB). The plasmid was sequenced and electroporated into WT C. glutamicum ATCC13032. Positive colonies were grown in BHI media supplemented with $25 \mu \mathrm{g} / \mathrm{ml}$ kanamycin overnight at $30^{\circ} \mathrm{C}$ and $120 \mathrm{rpm}$ shaking. The second round of recombination was selected by growth in minimal medium CGXII plates containing $10 \%(\mathrm{w} / \mathrm{v})$ sucrose. The insertion of the ino1 promoter was confirmed by colony PCR and sequenced (Eurofins, France). All the oligonucleotides used in order to obtain and check this strain are listed in the Supplementary Table 4.

For the construction of the sepF:scarlet strain, we fused at the $3^{\prime}$ of the endogenous $s e p F$ the gene encoding for scarlet spaced by a linker (LEGSGQGPGSGQGSGH). We used the pk19mobsacB strategy, in which sepF coding region with scarlet and $500 \mathrm{bp}$ down-stream of sepF were amplified from the pUMS4sepF-scarlet and chromosomal DNA of C. glutamicum ATCC13032 as a template, respectively. PCR fragments were assembled into the pk19mobsacB backbone by Gibson assembly obtaining the plasmid pk19-sepF:scarlet. The plasmid was sequenced and electroporated into WT C. glutamicum ATCC13032. Positive colonies were grown in BHI media supplemented with $25 \mu \mathrm{g} / \mathrm{ml}$ kanamycin overnight at $30^{\circ} \mathrm{C}$ and $120 \mathrm{rpm}$ shaking. The second round of recombination was selected by growth in BHI plates containing $10 \%(\mathrm{w} / \mathrm{v})$ sucrose The insertion of scarlet was confirmed by colony PCR and sequenced (Eurofins, France).

Growth curves. All strains were plated in CGXII media plates with $4 \%$ (w/v) sucrose as a carbon source for 2 days at $30^{\circ} \mathrm{C}$ and then single colonies were inoculated in $10 \mathrm{ml}$ of CGXII media $4 \%(\mathrm{w} / \mathrm{v})$ sucrose overnight at $30^{\circ} \mathrm{C}$ and $120 \mathrm{rpm}$ shaking. The next day, $20 \mathrm{ml}$ of CGXII media supplemented with the appropriate repressor or inducer were inoculated with the overnight cultures to a starting $\mathrm{OD}_{600}$ of $1 . \mathrm{OD}_{600}$ measurements were taken every $1.5 \mathrm{~h}$. Each growth curve represents the average of three different growth curves originally from three different single colonies. For each time point a sample for western blot was taken. When required, CGXII media $4 \%$ (w/v) sucrose was supplemented with either $1 \%(\mathrm{w} / \mathrm{v})$ myo-inositol, $50 \mathrm{ng} / \mathrm{ml}$ tetracycline or $1 \%(\mathrm{w} / \mathrm{v})$ gluconate and $25 \mathrm{\mu g} / \mathrm{ml}$ kanamycin.

Protein expression and purification. $\mathrm{N}$-terminal $6 \mathrm{xHis}$-SUMO-tagged SepF, and derivate mutants (both from C. glutamicum and M. tuberculosis) were expressed in E. coli BL21 (DE3) following an autoinduction protocol ${ }^{59}$. After $4 \mathrm{~h}$ at $37^{\circ} \mathrm{C}$ cells were grown for $20 \mathrm{~h}$ at $20^{\circ} \mathrm{C}$ in $2 \mathrm{YT}$ complemented autoinduction medium containing $50 \mu \mathrm{g} / \mathrm{ml}$ kanamycin. Cells were harvested and flash frozen in liquid nitrogen. Cell pellets were resuspended in $50 \mathrm{ml}$ lysis buffer $(50 \mathrm{mM}$ Hepes $\mathrm{pH} 8$ $300 \mathrm{mM} \mathrm{NaCl}, 5 \%$ glycerol, $1 \mathrm{mM} \mathrm{MgCl}_{2}$, benzonase, lysozyme, $0.25 \mathrm{mM}$ TCEP, EDTA-free protease inhibitor cocktails (ROCHE) at $4{ }^{\circ} \mathrm{C}$ and lysed by sonication. The lysate was centrifuged for $30 \mathrm{~min}$ at $30,000 \times g$ at $4^{\circ} \mathrm{C}$. The cleared lysate was loaded onto a Ni-NTA affinity chromatography column (HisTrap FF crude, GE Healthcare). His-tagged proteins were eluted with a linear gradient of buffer B (50 $\mathrm{mM}$ Hepes $\mathrm{pH} 8,300 \mathrm{mM} \mathrm{NaCl}, 5 \%$ glycerol, $1 \mathrm{M}$ imidazole). The eluted fractions containing the protein of interest were pooled and either dialyzed directly (for SPR experiments) or dialyzed in the presence of the SUMO protease (ratio used, 1:100) Dialysis was carried out at $4{ }^{\circ} \mathrm{C}$ overnight in $50 \mathrm{mM}$ Hepes $\mathrm{pH} 8,150 \mathrm{mM} \mathrm{NaCl}$, $5 \%$ glycerol, $0.25 \mathrm{mM}$ TCEP. Cleaved His-tags and His-tagged SUMO protease were removed with Ni-NTA agarose resin. The cleaved protein was concentrated and loaded onto a Superdex 75 16/60 size exclusion (SEC) column (GE Healthcare) pre-equilibrated at $4{ }^{\circ} \mathrm{C}$ in $50 \mathrm{mM}$ Hepes pH $8,150 \mathrm{mM} \mathrm{NaCl}, 5 \%$ glycerol. The peak corresponding to the protein was concentrated, flash frozen in small aliquots in liquid nitrogen and stored at $-80^{\circ} \mathrm{C}$.

Codon optimized N-terminal 6xHis-SUMO-tagged C. glutamicum FtsZ was produced and purified as described above, except that $\mathrm{KCl}$ was used instead of $\mathrm{NaCl}$ and a TALON FF crude column (GE Healthcare) was used for affinity chromatography. All purified proteins used in this work have been run on an sodium dodecyl sulfate-polyacrylamide gel electrophoresis (SDS-PAGE) and are represented in Supplementary Fig. 22.

Crystallization. Crystallization screens were performed for the different SepF constructs and SepF-FtsZ $\mathrm{CTD}_{\mathrm{C}}$ complexes using the sitting-drop vapor diffusion method and a Mosquito nanolitre-dispensing crystallization robot at $18^{\circ} \mathrm{C}$ (TTP Labtech, Melbourn, UK). Optimal crystals of $\operatorname{SepF}_{\Delta \mathrm{ML}}(13 \mathrm{mg} / \mathrm{ml})$ were obtained after one week in 10\% PEG 8000, 0.2 M Zinc acetate, $0.1 \mathrm{M}$ sodium acetate. The complex SepF $F_{\triangle M L}-F_{t s} Z_{C T D}$ (DDLDVPSFLQ, purchased from Genosphere) was crystallized at $10 \mathrm{mg} / \mathrm{ml} \mathrm{SepF}_{\triangle \mathrm{ML}}$ and $5.8 \mathrm{mg} / \mathrm{ml}$ of FtsZ $\mathrm{CTD}_{\mathrm{CT}}(1: 5$ molar ratio) after 2 weeks in $100 \mathrm{mM}$ sodium acetate $\mathrm{pH} 4.6$, and $30 \% \mathrm{w} / \mathrm{v}$ PEG 4000 . SepF $\mathrm{F}_{\Delta \mathrm{ML}, \Delta \mathrm{a} 3}$ $(17 \mathrm{mg} / \mathrm{ml})$ crystallized within 2 weeks in $0.1 \mathrm{M} \mathrm{MES} \mathrm{pH} \mathrm{6,20 \% w/v} \mathrm{PEG} \mathrm{MME}$ 2000 and $0.2 \mathrm{M} \mathrm{NaCl}$. The $\mathrm{SepF}_{\Delta \mathrm{ML}, \Delta \alpha 3}-\mathrm{FtsZ}_{\mathrm{CTD}}$ complex was crystallized at $17 \mathrm{mg} / \mathrm{ml} \mathrm{SepF} \mathrm{MML}, \Delta \alpha 3$ and $9.8 \mathrm{mg} / \mathrm{ml} \mathrm{FtsZ} \mathrm{CTD}_{\mathrm{C}}(1: 5$ molar ratio) within 2 weeks in $0.1 \mathrm{M} \mathrm{MgCl}_{2}, 0.1 \mathrm{M}$ MES pH 6.5 and $30 \%$ w/v PEG 400 buffer. Crystals were cryo-protected in mother liquor containing $33 \%(\mathrm{vol} / \mathrm{vol})$ ethylene glycol or $33 \%$ (vol/vol) glycerol. 
Data collection, structure determination, and refinement. X-ray diffraction data were collected at $100 \mathrm{~K}$ using beamlines ID30B and ID23-1 (wavelength $=0.97625 \AA$ ) at the ESRF (Grenoble, France). All datasets were processed using $\mathrm{XDS}^{60}$ and AIMLESS from the CCP4 suite ${ }^{61}$. The crystal structures were determined by molecular replacement methods using Phaser ${ }^{62}$ and C. glutamicum SepF (PDB code 3p04) as the probe model. In the case of $\mathrm{SepF}_{\Delta \mathrm{ML}}$, the structure was also independently determined by single-wavelength anomalous diffraction (SAD) phasing using Patterson methods to localize the protein-bound $\mathrm{Zn}$ ions (present in the crystallization buffer) with SHELXD ${ }^{63}$ and automatic model building with Buccaneer from the CCP4 suite ${ }^{64}$. All structures were refined through iterative cycles of manual model building with $\mathrm{COOT}^{65}$ and reciprocal space refinement with BUSTER ${ }^{66}$. Highly anisotropic diffraction was observed for $\mathrm{SepF}_{\Delta \mathrm{ML}, \Delta \mathrm{a} 3}$ crystals, in which one of the two monomers in the asymmetric unit was largely exposed to solvent (see Supplementary Fig. 13c), and exhibited unusually high-temperature factors (average B values for all main-chain atoms of the two monomers were, respectively, $17 \AA^{2}$ and $58 \AA^{2}$ ). The crystallographic statistics are shown in Supplementary Table 1 and representative views of the final electron density map for each structure are shown in Supplementary Fig. 23. Structural figures were generated with Chimera ${ }^{67}$ or Pymol (The PyMOL Molecular Graphics System, Version 2.0 Schrödinger, LLC). Atomic coordinates and structure factors have been deposited in the protein data bank under the accession codes 6sat, 6scp, 6scq, and 6scs.

FtsZ and SepF polymerization assay. Purified FtsZ and SepF were precleared at $25,000 \times g$ for $15 \mathrm{~min}$ at $4{ }^{\circ} \mathrm{C}$. FtsZ with or without SepF was added to a final concentration of $15 \mu \mathrm{M}$ each in $100-500 \mu \mathrm{l}$ final volume in polymerization buffer $\left(100 \mathrm{mM} \mathrm{KCl}, 10 \mathrm{mM} \mathrm{MgCl}_{2}, 25 \mathrm{mM}\right.$ Pipes $\mathrm{pH}$ 6.9). The mixture was placed into a quartz cuvette with a light path of $10 \mathrm{~mm}$ or a 96 -well plate and $0.5-2 \mathrm{mM} \mathrm{GTP}$ or GMPCPP were added to the reaction mixture. Data acquisition started immediately using an UV-Visible Spectrophotometer (Thermo scientific Evolution 220) during $600 \mathrm{~s}$ at $25^{\circ} \mathrm{C}$ using $400 \mathrm{~nm}$ for excitation and emission and spectra with slits widths of $1 \mathrm{~nm}$ or a Varioskan ${ }^{\mathrm{mw}}$ LUX plate reader (Thermo Fisher Scientific) with an excitation of $400 \mathrm{~nm}$. Experiments were done in triplicates and measurements were taken every $15 \mathrm{~s}$ during $600 \mathrm{~s}$ and keeping a constant temperature of $25^{\circ} \mathrm{C}$.

To follow the polymerization of SepF in the presence of lipids, we used SepF or SepF mutants plus SUVs at a final concentration of $50 \mu \mathrm{M}$ each in polymerization buffer. The mixture was placed into a quartz cuvette with a light path of $10 \mathrm{~mm}$ and data acquisition was carried out as mentioned above. When used, Fts $Z_{\text {CTD }}$ was added at a final concentration of $100 \mu \mathrm{M}$.

Small unilamellar vesicle (SUV) preparation. Reverse phase evaporation was used to prepare small unilamellar vesicles (SUVs). A $10 \mathrm{mM}$ lipid solution made of an 8:2 mixture of 1-palmitoyl-2-oleoyl phosphatidylcholine (POPC) and 1-palmitoyl-2-oleoylglycero-3-phosphoglycerol (POPG) (Avanti Polar Lipids) was prepared as described ${ }^{68}$. Chloroform was removed by evaporation under vacuum conditions and the dried phospholipid film was resuspended in a mixture of diethyl ether and buffer ( $25 \mathrm{mM}$ Hepes pH 7.4, $10 \mathrm{mM} \mathrm{MgCl}_{2}$ and $\left.150 \mathrm{mM} \mathrm{KCl}\right)$. Diethyl ether was eliminated by reverse phase evaporation and by slowly decreasing the pressure to the vacuum. SUVs were obtained by sonication during $30 \mathrm{~min}$ at $4{ }^{\circ} \mathrm{C}$. The diameter and charge of SUV were determined by measuring dynamic light scattering (DLS) and electrophoretic mobility profiles on a Zetasizer Nano instrument (Malvern Instruments).

Real-time surface plasmon resonance (SPR). All experiments were carried out on a Biacore T200 instrument (GE Healthcare Life Sciences) equilibrated at $25^{\circ} \mathrm{C}$ in $25 \mathrm{mM}$ HEPES $\mathrm{pH} 8,150 \mathrm{mM} \mathrm{KCl}, 0.1 \mathrm{mM}$ EDTA. For SPR surface preparation His6-Sumo tagged constructs of $\operatorname{SepF}_{\triangle M L}$, $\operatorname{SepF}_{\triangle M L, F 131 \mathrm{~A}}, \mathrm{SepF}_{\triangle \mathrm{ML}, \mathrm{K} 125 \mathrm{E} / \mathrm{F} 131 \mathrm{~A}}$ were covalently immobilized on 3 independent flow-cells of an NTA sensorchips (GE Healthcare Life Sciences) as previously described ${ }^{69}$. The final immobilization densities of SepF variants ranged from 3000 to 4000 resonance units $(\mathrm{RU} ; 1 \mathrm{RU} \approx$ 1 pg per $\mathrm{mm}^{2}$ ).

For SPR-binding assays, different concentrations of the FtsZ $\mathrm{Z}_{\mathrm{CTD}}$ peptide (ranging from 1.56 to $400 \mu \mathrm{M}$ ) were injected sequentially at $50 \mu \mathrm{l} / \mathrm{min}$ on the SepFfunctionalized surfaces. Association was monitored for $30 \mathrm{~s}$, followed by a buffer wash for $120 \mathrm{~s}$ during which the full dissociation of the SepF-FtsZ $\mathrm{CTD}_{\mathrm{CT}}$ complex was observed. The concentration dependence of the SPR steady-state signals $\left(R_{\mathrm{eq}}\right)$ was analyzed, allowing to determine the equilibrium dissociation constant $\mathrm{Kd}$, by fitting the dose/response curve with the equation $R_{\mathrm{eq}}=R_{\max } * C / \mathrm{Kd}+C$ (where $C$ is the concentration of Fts $\mathrm{Z}_{\mathrm{CTD}}$ and $R_{\max }$ the response at infinite peptide concentration).

Phase contrast and fluorescence microscopy. For imaging, cultures of C. glutamicum were grown in BHI or minimal medium CGXII during the day, and washed and inoculated into CGXII media for overnight growth. The following day cultures were diluted to $\mathrm{OD}_{600}=1$ and grown to the required $\mathrm{OD}$ (early exponential phase) for imaging. For HADA labeling, cultures were incubated with $0.5 \mathrm{mM}$ HADA for $20 \mathrm{~min}$ at $30^{\circ} \mathrm{C}$ in the dark. Two percent agarose pads were prepared with the corresponding growth medium and cells were visualized using a Zeiss Axio Observer Z1 microscope fitted with an Orca Flash 4 V2 sCMOS camera (Hamamatsu), and a Pln-Apo 63×/1.4 oil Ph3 objective. Images were collected using Zen Blue 2.6 (Zeiss) and analyzed using the software Fiji ${ }^{70}$ and the plugin
Microbe $^{71}$ to generate violin plots and fluorescent intensity heatmaps. Statistical analyses of cell lengths are summarized in Supplementary Tables 5 and 6 . The experiments were performed as biological triplicates. Some autofluorescence is observed for wild-type C. glutamicum as shown in Supplementary Fig. 24.

Western blots. To prepare cell extracts, bacterial cell pellets were resuspended in lysis buffer (50 mM Bis-Tris pH 7.4; $75 \mathrm{mM}$ 6-Aminocaproic Acid; $1 \mathrm{mM}$ MgSO4; Benzonase and protease Inhibitor), and disrupted at $4{ }^{\circ} \mathrm{C}$ with $0.1 \mathrm{~mm}$ glass beads and using a PRECELLYS 24 homogenizer. Crude extracts $(120 \mu \mathrm{g})$ were analyzed by SDS-PAGE, electro-transferred onto a $0.2 \mu \mathrm{m}$ Nitrocellulose membrane and blocked with $5 \%(\mathrm{w} / \mathrm{v})$ skimmed milk. Membranes were incubated with an anti-SepF antibody (produced by Covalab, Supplementary Fig. 25a), an antiFtsZ antibody (produced by Proteogenix, Supplementary Fig. 25b) or an antimNeonGreen antibody (purchased from Chromotek) for $1 \mathrm{~h}$ at room temperature. After washing in TBS-Tween buffer (Tris- $\mathrm{HCl}$ pH $810 \mathrm{mM}$; NaCl $150 \mathrm{mM}$; Tween $200,05 \%$ (vol/vol), the membrane was incubated with an anti-rabbit horseradish peroxidase-linked antiserum (GE healthcare) for $45 \mathrm{~min}$. The membrane was washed and revealed with HRP substrate (Immobilon Forte, Millipore) and imaged using the ChemiDoc MP Imaging System (BIORAD). All uncropped blots are shown in Supplementary Fig. 26.

SepF and FtsZ quantification. In order to quantify the amount of SepF and FtsZ in the cell, purified recombinant SepF and FtsZ were serially diluted from $50 \mathrm{ng}$ to $1.65 \mathrm{ng}$ and loaded in a $12 \%$ gel. Proteins were electro-transferred onto a nitrocellulose membrane and immunodetected with the corresponding antibody. Quantification of the bands was performed using the software Image Lab (Biorad) and the band volume was plotted against the ng loaded in order to obtain a strand curve. C. glutamicum ATCC13032 was grown in CGXII media with $4 \%$ sucrose or $4 \%$ sucrose $+1 \%$ gluconate. Two time points were harvested at $6 \mathrm{~h}$ and $24 \mathrm{~h}(\mathrm{ON})$ and cell pellets were prepared as described above. $60 \mu \mathrm{g}$ of the whole-cell extracts were loaded in a $12 \%$ gel and electro-transferred onto a nitrocellulose membrane SepF and FtsZ antibodies were used to detect the proteins in the cell extracts and quantified using the volume tool in the Image Lab software.

Electron microscopy. For negative stain sample preparations, incubations were performed at room temperature. SUVs and SepF constructs $(50 \mu \mathrm{M})$ were incubated in polymerization buffer ( $100 \mathrm{mM} \mathrm{KCl}, 10 \mathrm{mM} \mathrm{MgCl}_{2}, 25 \mathrm{mM}$ Pipes pH 6.9) for $10 \mathrm{~min}$. When used, Fts $Z_{\text {СтD }}$ was added at a final concentration of $100 \mu \mathrm{M}$. To image the FtsZ polymers with and without SepF, we used a final concentration of protein at $21 \mu \mathrm{M}$ and $13 \mu \mathrm{M}$, respectively, in EM buffer containing $50 \mathrm{mM}$ HEPES $\mathrm{pH} 7.4,300 \mathrm{mM} \mathrm{KCl}$, and $10 \mathrm{mM} \mathrm{MgCl}$ supplemented with $3 \mathrm{mM}$ GTP. FtsZ was incubated with or without SepF at room temperature and imaged after $10 \mathrm{~min}$.

To image SepF rings form $M$. tuberculosis, $M t b \mathrm{SepF}_{\Delta \mathrm{ML}}$ was used at a final concentration of $50 \mu \mathrm{M}$ in buffer containing $50 \mathrm{mM}$ HEPES pH 7.4, $300 \mathrm{mM} \mathrm{KCl}$ and $10 \mathrm{mM} \mathrm{MgCl}$. For all samples, 400 mesh carbon coated grids (Electron Microscopy Sciences; CF 400-Cu) were glow-discharged on an ELMO system for $30 \mathrm{sec}$ at $2 \mathrm{~mA}$. $5 \mu \mathrm{l}$ samples were applied onto the grids and incubated for $30 \mathrm{~s}$, the sample was blotted, washed in 3 drops of water and then stained with $2 \%$ (weight/ vol) uranyl acetate. Images were recorded on a Gatan UltraScan 4000 charged coupled device (CCD) camera (Gatan) on a Tecnai T12 BioTWINLaB6 electron microscope operating at a voltage of $120 \mathrm{kV}$.

For cryo-EM, the ternary complex was prepared by incubating $100 \mu \mathrm{M}$ SUVs, $10 \mu \mathrm{M}$ SepF and $10 \mu \mathrm{M}$ FtsZ in polymerization buffer $(100 \mathrm{mM} \mathrm{KCl}, 10 \mathrm{mM}$ $\mathrm{MgCl}_{2}, 25 \mathrm{mM}$ Pipes pH 6.9; $3 \mathrm{mM}$ GTP) for $10 \mathrm{~min}$ at room temperature. $5 \mu \mathrm{l}$ of sample were deposited onto glow-discharged lacey carbon copper grids (Ted Pella) and plunge-frozen in liquid ethane using a Leica EM-CPC. Cryo-EM data acquisition was performed on a JEOL 2200FS (Jeol, Japan) $200 \mathrm{kV}$ cryo-electron microscope equipped with an Omega in-column energy filter. High magnification $(30,000 \times$, corresponding pixel size $0.32 \mathrm{~nm})$ zero-loss (slit: $20 \mathrm{eV})$ images were collected at nominal defocus between 1 and $4 \mu \mathrm{m}$ depending on the experiment on a Gatan USC1000 slow scan CCD camera.

Mass spectrometry. Strains expressing Scarlet, SepF-Scarlet, and SepF ${\mathrm{K} 125 \mathrm{E} / \mathrm{F} 131 \mathrm{~A}^{-}}^{-}$ Scarlet were grown in CGXII minimal media supplemented with $4 \%$ sucrose and $1 \%$ gluconate for $6 \mathrm{~h}$ at $30^{\circ} \mathrm{C}$. Cells were harvested, washed, and normalized by resuspending cell pellets in PBS-T (1X PBS, $0.1 \% \mathrm{v} / \mathrm{v}$ Tween-80) to give a final $\mathrm{OD}_{600}$ of 3 . The cell suspensions were cross-linked with $0.25 \% \mathrm{v} / \mathrm{v}$ of formaldehyde for $20 \mathrm{~min}$ at $30^{\circ} \mathrm{C}$ with gentle agitation. The crosslinking reaction was stopped by adding $1.25 \mathrm{M}$ glycine and incubated for $5 \mathrm{~min}$ at room temperature. Cells were resuspended in $50 \mathrm{mM}$ Bis-Tris $\mathrm{pH}$ 7.4, $75 \mathrm{mM}$ aminocaproic acid, $1 \mathrm{mM} \mathrm{MgSO}$, $1 \times$ Benzonase, $1 \times$ Complete Protease inhibitors cocktail (ROCHE) and disrupted at $4^{\circ} \mathrm{C}$ with $0.1 \mathrm{~mm}$ glass beads and using a PRECELLYS 24 homogenizer. After lysis, $0.1 \% \mathrm{n}$-Dodecyl- $\beta$-D-Maltopyranoside was added and the total extract was incubated for $1 \mathrm{~h}$ at $4{ }^{\circ} \mathrm{C}$. Cell lysates were centrifuged at $4{ }^{\circ} \mathrm{C}$ for $10 \mathrm{~min}$ at $14,000 \mathrm{rpm}$ and the soluble fraction was collected and protein levels quantified.

Detergent-solubilized protein extracts were incubated with $50 \mu \mathrm{l}$ of magnetic beads cross-linked with $10 \mu \mathrm{g}$ of purified anti-Scarlet antibody (produced by Covalab). Beads were collected with a magnetic stand and washed three times with lysis buffer and bound material was eluted in $0.1 \mathrm{M}$ glycine $\mathrm{pH} 2.5$ for $10 \mathrm{~min}$ at 
$4{ }^{\circ} \mathrm{C}$, and immediately neutralized by adding $1 \mathrm{M}$ Tris $\mathrm{pH} 9$. The protein samples were reduced, denatured ( $2 \mathrm{M}$ Urea) and alkylated with iodoacetamide prior to treatment with trypsin. Tryptic digests were cleaned on a POROS ${ }^{\mathrm{TM}} \mathrm{R} 2$ resin (Thermo Fisher), vacuum dried and resuspended in phase A buffer $(0.1 \%$ formic acid). Tryptic peptides from three replicates of each condition were analyzed using a nano-HPLC (Ultimate 3000, Thermo) coupled to a hybrid quadrupole-orbitrap mass spectrometer (Q-Exactive Plus, Thermo). Peptide mixtures were separated on a C18 column (PepMap ${ }^{\circledast}$ RSLC, $0.075 \times 500 \mathrm{~mm}, 2 \mu \mathrm{m}, 100 \AA$ ) using a $65 \mathrm{~min}$ gradient of mobile phase B from 0 to $55 \%$ (A: $0.1 \%$ formic acid; B: $0.1 \%$ formic acid in acetonitrile). Online MS analysis was carried out in a data-dependent mode (MS followed by MS/MS of the top 12 ions) using a dynamic exclusion list. PatternLab for Proteomics software ${ }^{72}$ was used for protein identification against a targetreverse C. glutamicum database (Uniprot November 2018) to which the sequences of Scarlet, SepF-Scarlet and SepF $\mathrm{K}_{\mathrm{K} 125 \mathrm{E} / \mathrm{F} 131 \mathrm{~A}}$-Scarlet were added.

Patternlab for proteomics was used for label-free quantitation analyses using extracted ion chromatogram (XIC). To calculate fold enrichment of FtsZ in pull down analyses, FtsZ signals ( $\Sigma$ XIC signal of detected peptides in each replicate) were normalized by comparing the ratio FtsZ/SepF in each case (for that we considered the intensity of SepF as (SepF-Scarlet minus Scarlet) or $\left(\mathrm{SepF}_{\mathrm{K} 125 \mathrm{E} / \mathrm{F} 131 \mathrm{~A}-\mathrm{Scarlet}}\right.$ minus Scarlet)). The results are shown in Supplementary Table 2.

Dynamic light scattering. Before DLS experiments, protein samples were centrifuged at $25,000 \times g$ for $15 \mathrm{~min}$ at $4^{\circ} \mathrm{C}$. SUVs with or without SepF (or SepF mutants) were used at a final concentration of $50 \mu \mathrm{M}$ each in $100 \mathrm{mM} \mathrm{KCl}, 10 \mathrm{mM}$ $\mathrm{MgCl}_{2}$, and $25 \mathrm{mM}$ Pipes pH 6.9 Buffer and the reaction was carried out for $10 \mathrm{~min}$ at room temperature. Polydispersity of the samples was measured using Dyna-pro Plate Reader (Wyatt technology) equipped with an $830 \mathrm{~nm}$ laser and a temperature control module. The Dynamics software (version 7.9) was used to schedule data acquisition and data analysis. For each well, 20 measurements of $10 \mathrm{~s}$ were averaged and this operation was repeated 20 times for each condition at $25^{\circ} \mathrm{C}$. For samples containing $\mathrm{FtsZ}_{\mathrm{CTD}}$, the peptide was used at a final concentration of $100 \mu \mathrm{M}$. All the experiments were carried out as minimum three biological and technical replicates.

Analytical ultracentrifugation (AUC). Protein samples were desalted using a PD Minitrap G-25 column (Sigma-Aldrich) into AUC buffer (50 mM Hepes pH 7.4, $150 \mathrm{mM} \mathrm{KCl}, 10 \mathrm{mM} \mathrm{MgCl} 2$ ) and analyzed at $1-2 \mathrm{mg} / \mathrm{ml}$ concentration. Samples were centrifuged at $42,000 \mathrm{rpm}$ in a Beckman Coulter XL-1 analytical ultracentrifuge at $20^{\circ} \mathrm{C}$ in a four-hole AN 60 -Ti rotor equipped with $12-\mathrm{mm}$ doublesector epoxy centerpieces. Detection of SepF concentration as a function of radial position and time was performed by optical density measurements at $280 \mathrm{~nm}$ and interferometry. Data analysis for sedimentation velocity was performed by continuous size distribution $\mathrm{c}(\mathrm{s})$ using Sedfit software version 15.01

GTPase activity assay. The FtsZ GTPase activity was measured by detection of free phosphate using Biomol Green (Enzo Life Science). F15 $\mu \mathrm{M}$ of SepF and $15 \mu \mathrm{M}$ of FtsZ with or without $15 \mu \mathrm{M}$ of SepF were incubated at $4^{\circ} \mathrm{C}$ for $5 \mathrm{~min}$ in polymerization buffer (100 mM KCl, $10 \mathrm{mM} \mathrm{MgCl2,} 25 \mathrm{mM}$ Pipes pH 6.9). After, $100 \mu \mathrm{l}$ of the mixture were place in a 96-well-plate that contained GTP at $2 \mathrm{mM}$ final concentration. Reactions were incubated at room temperature for $10 \mathrm{~min}$ and $100 \mu \mathrm{l}$ of the developing reagent was added. The mixture was incubated at room temperature for $25 \mathrm{~min}$ to allow development of the green color and absorbance was measured at $620 \mathrm{~nm}$ using a Varioskan ${ }^{\mathrm{nt}}$ LUX (Thermo Fisher Scientific). Reactions were performed in triplicate for each condition. Obtained values were normalized by the lowest SepF value and free phosphate was measured by comparison to a phosphate standard curve.

Far-UV circular dichroism. The secondary structure of $\mathrm{SepF}_{\mathrm{M}}$ in the presence or absence of SUVs was determined using synchrotron radiation circular dichroism (SRCD) carried out at the beamline DISCO (SOLEIL, Gif-sur-Yvette, France). Three individual scans were averaged to obtain final far-UV spectra. Measurements were made at $25^{\circ} \mathrm{C}$ with an integration time of $1.2 \mathrm{~s}$ and bandwidth of $1 \mathrm{~nm}$. SRCD spectra in the far-UV (190 to $250 \mathrm{~nm}$ ) were recorded using QS cells (Hellma, France) with a path length of $100 \mu \mathrm{m}$. SepF $\mathrm{M}_{\mathrm{M}}$ was used at $100 \mu \mathrm{M}$ in CD buffer $(25 \mathrm{mM}$ Hepes pH 7.4, $100 \mathrm{mM} \mathrm{KCl}$ ) in the presence and absence of SUVs (POPC: POPG 8:2) at a final concentration of $2 \mathrm{mM}$. As a blank, the CD buffer was used in the absence or presence of SUVs, and subtracted from far-UV CD spectra. Finally, BestSel ${ }^{73}$ was used in order to estimate the content of secondary structure.

Lipid peptide interaction (tryptophan fluorescence emission titration). To estimate the partition coefficient $\left(K_{\mathrm{x}}\right)$ between SUVs and SepF, we used the synthetic peptide MSMLKKTKEFFGLAW (purchased from Genosphere), which contains the $\mathrm{SepF}_{\mathrm{M}}$ sequence with an extra $\mathrm{W}$ residue at the C-terminal. $K_{\mathrm{x}}$ is defined as the ratio of peptide concentration in the lipid and in the buffer phases. $K_{\mathrm{x}}$ can be expressed by the following equation:

$$
K_{\mathrm{X}}=\frac{P_{\mathrm{L}} /\left(P_{\mathrm{L}}+[L]\right)}{P_{\mathrm{W}} /\left(P_{\mathrm{W}}+[W]\right)}
$$

in which $P_{\mathrm{W}}$ represents the concentration of soluble peptide (in aqueous phase) and $P_{\mathrm{L}}$ the peptide concentration bound to lipid membranes (lipidic phase). [L] refers to the lipid concentration and [W] refers to the water concentration. $K_{\mathrm{x}}$ is directly related to the apparent dissociation constant as $K_{\mathrm{x}}{ }^{*} \mathrm{Kd}=[\mathrm{W}]$ with $\mathrm{Kd}{ }^{*}$ $P_{\mathrm{L}}=P_{\mathrm{W}} *[\mathrm{~L}]$. The KaleidaGraph software was used to fit the $K_{\mathrm{x}}$ to the experimental data (for details, see ref. ${ }^{68}$ ).

We used a FP-8200 (Jasco, Tokyo, Japan) spectrophotometer equipped with a thermostatic Peltier ETC-272T at $25^{\circ} \mathrm{C}$. Experiments were performed in a cuvette 109.004F-QS (Hellma, France) containing a magnetic stirrer. A bandwidth of $5 \mathrm{~nm}$ was used for emission and excitation. One micromolar of peptide was used in Titration buffer $(100 \mathrm{mM} \mathrm{KCl}$ and $25 \mathrm{mM}$ Hepes $\mathrm{pH}$ 7.4). We measured the florescence emission between 300 and $400 \mathrm{~nm}$ at a scan rate of $125 \mathrm{~nm} / \mathrm{min}$ with an excitation wavelength of $280 \mathrm{~nm}$. The obtained spectra were corrected by blank subtraction (SUV light scattering in titration buffer). Next, the maximum wavelength value $\left(\lambda_{\max }\right)$ and the fluorescence ratio $330 / 370$ were calculated to measure the partition coefficient $\left(K_{\mathrm{x}}\right)$.

Phylogenetic analysis. We performed sequence homology searches with HMMER $^{74}$ using SEPF_BACSU/ Q8NNN6_CORGL as queries against the UniprotKB database. More than 4000 sequences were then clustered at $76 \%$ with $C D$ HIT, and after removal of short ( $<120$ residues) and long $(>240)$ candidates, 1800 sequences were kept. Redundancy was further reduced at 50\% sequence identity with clustering programs CD-HIT ${ }^{75}$ and MMseqs $2^{76}$ separately, merging both outputs and removing duplicate sequences. We used this non-redundant dataset of 839 sequences with wide taxonomic distribution to compute a multiple alignment with MAFFT ${ }^{77}$ (l-insi option). Before phylogenetic reconstruction, we used trimAL ${ }^{78}$ to remove columns with $>80 \%$ gaps. Finally, we built the SepF tree with PhyML $3.3^{79}$ using the LG+CAT substitution model, chosen with SMS ${ }^{80}$. Trees were visualized using FigTree v1.4.3.

Reporting summary. Further information on research design is available in the Nature Research Reporting Summary linked to this article.

\section{Data availability}

The crystallographic data is available from the Protein Data Bank (www.rcsb.org), under the accession numbers (PDB codes) reported in Supplementary Table 1. The source data underlying Figs. 1b, d, 2e, 3a, 3b, and $5 \mathrm{f}$ and Supplementary Figs 1a, 1c, 2b, 4c, 5a, 7c, 7d, $11 \mathrm{~b}, 16,19 \mathrm{~b}, 20 \mathrm{~b}, 20 \mathrm{~d}$, and 21 are provided as a Source Data file. All other data are available from the corresponding authors upon request.

Received: 28 August 2019; Accepted: 9 March 2020;

Published online: 02 April 2020

\section{References}

1. Bi, E. F. \& Lutkenhaus, J. FtsZ ring structure associated with division in Escherichia coli. Nature 354, 161-164 (1991).

2. Du, S. \& Lutkenhaus, J. At the Heart of Bacterial Cytokinesis: the Z Ring. Trends Microbiol. 27, 1-11 (2019).

3. Levin, P. A., Kurtser, I. G. \& Grossman, A. D. Identification and characterization of a negative regulator of FtsZ ring formation in Bacillus subtilis. Proc. Natl Acad. Sci. USA 96, 9642-9647 (1999).

4. Gueiros-Filho, F. J. \& Losick, R. A widely conserved bacterial cell division protein that promotes assembly of the tubulin-like protein FtsZ. Genes Dev. 16, 2544-2556 (2002).

5. Ebersbach, G., Galli, E., Møller-Jensen, J., Löwe, J. \& Gerdes, K. Novel coiledcoil cell division factor ZapB stimulates $\mathrm{Z}$ ring assembly and cell division. Mol. Microbiol. 68, 720-735 (2008).

6. Durand-Heredia, J. M., Yu, H. H., De Carlo, S., Lesser, C. F. \& Janakiraman, A Identification and characterization of ZapC, a stabilizer of the FtsZ ring in Escherichia coli. J. Bacteriol. 193, 1405-1413 (2011).

7. Durand-Heredia, J., Rivkin, E., Fan, G., Morales, J. \& Janakiraman, A. Identification of ZapD as a cell division factor that promotes the assembly of FtsZ in Escherichia coli. J. Bacteriol. 194, 3189-3198 (2012).

8. Pichoff, S. \& Lutkenhaus, J. Tethering the $\mathrm{Z}$ ring to the membrane through a conserved membrane targeting sequence in FtsA. Mol. Microbiol. 55, 1722-1734 (2005)

9. Hale, C. A. \& de Boer, P. A. Direct binding of FtsZ to ZipA, an essential component of the septal ring structure that mediates cell division in E. coli. Cell 88, 175-185 (1997).

10. Loose, M. \& Mitchison, T. J. The bacterial cell division proteins FtsA and FtsZ self-organize into dynamic cytoskeletal patterns. Nat. Cell Biol. 16, 38-46 (2014).

11. Duman, R. et al. Structural and genetic analyses reveal the protein SepF as a new membrane anchor for the Z ring. Proc. Natl Acad. Sci. USA 110, E4601-E4610 (2013). 
12. Bernhardt, T. G. \& de Boer, P. A. J. SlmA, a nucleoid-associated, FtsZ binding protein required for blocking septal ring assembly over chromosomes in $E$. coli. Mol. Cell 18, 555-564 (2005).

13. Wu, L. J. \& Errington, J. Coordination of cell division and chromosome segregation by a nucleoid occlusion protein in Bacillus subtilis. Cell 117, 915-925 (2004).

14. Shen, B. \& Lutkenhaus, J. The conserved C-terminal tail of FtsZ is required for the septal localization and division inhibitory activity of MinC(C)/MinD. Mol. Microbiol. 72, 410-424 (2009).

15. Ma, X. \& Margolin, W. Genetic and functional analyses of the conserved Cterminal core domain of Escherichia coli FtsZ. J. Bacteriol. 181, 7531-7544 (1999).

16. Donovan, C. \& Bramkamp, M. Cell division in Corynebacterineae. Front. Microbiol. 5, 132 (2014).

17. Letek, M. et al. Cell growth and cell division in the rod-shaped actinomycete Corynebacterium glutamicum. Antonie Van. Leeuwenhoek 94, 99-109 (2008).

18. Ishikawa, S., Kawai, Y., Hiramatsu, K., Kuwano, M. \& Ogasawara, N. A new FtsZinteracting protein, YlmF, complements the activity of FtsA during progression of cell division in Bacillus subtilis. Mol. Microbiol. 60, 1364-1380 (2006).

19. Hamoen, L. W., Meile, J. -C., de Jong, W., Noirot, P. \& Errington, J. SepF, a novel FtsZ-interacting protein required for a late step in cell division. Mol. Microbiol. 59, 989-999 (2006).

20. Gola, S., Munder, T., Casonato, S., Manganelli, R. \& Vicente, M. The essential role of SepF in mycobacterial division. Mol. Microbiol. 97, 560-576 (2015).

21. Marbouty, M., Saguez, C., Cassier-Chauvat, C. \& Chauvat, F. Characterization of the FtsZ-interacting septal proteins SepF and Ftn6 in the spherical-celled cyanobacterium Synechocystis strain PCC 6803. J. Bacteriol. 191, 6178-6185 (2009).

22. Gündoğdu, M. E. et al. Large ring polymers align FtsZ polymers for normal septum formation. EMBO J. 30, 617-626 (2011).

23. Krupka, M. et al. Role of the FtsA $\mathrm{C}$ terminus as a switch for polymerization and membrane association. mBio, https://doi.org/10.1128/mBio.02221-14 (2014).

24. Krupka, M. et al. Escherichia coli FtsA forms lipid-bound minirings that antagonize lateral interactions between FtsZ protofilaments. Nat. Commun. 8, 1-12 (2017).

25. Conti, J., Viola, M. G. \& Camberg, J. L. FtsA reshapes membrane architecture and remodels the Z-ring in Escherichia coli. Mol. Microbiol. 107, 558-576 (2018).

26. Honrubia, M. P., Ramos, A. \& Gil, J. A. The cell division genes ftsQ and ftsZ, but not the three downstream open reading frames YFIH, ORF5 and ORF6, are essential for growth and viability in Brevibacterium lactofermentum ATCC 13869. Mol. Genet. Genomics 265, 1022-1030 (2001).

27. Baumgart, M. et al. IpsA, a novel LacI-type regulator, is required for inositolderived lipid formation in Corynebacteria and Mycobacteria. BMC Biol. 11, 122 (2013).

28. Pfeifer-Sancar, K., Mentz, A., Rückert, C. \& Kalinowski, J. Comprehensive analysis of the Corynebacterium glutamicum transcriptome using an improved RNAseq technique. BMC Genomics 14, 888 (2013).

29. Baranowski, C., Rego, E. H. \& Rubin, E. J. The dream of a Mycobacterium. Microbiol. Spectr. 7, 1-14 (2019).

30. Nilsen, T., Ghosh, A. S., Goldberg, M. B. \& Young, K. D. Branching sites and morphological abnormalities behave as ectopic poles in shape-defective Escherichia coli. Mol. Microbiol. 52, 1045-1054 (2004).

31. Wells, V. L. \& Margolin, W. A new slant to the $\mathrm{Z}$ ring and bacterial cell branch formation. Mol. Microbiol. 84, 199-202 (2012).

32. Kuru, E., Tekkam, S., Hall, E., Brun, Y. V. \& Van Nieuwenhze, M. S. Synthesis of fluorescent D-amino acids and their use for probing peptidoglycan synthesis and bacterial growth in situ. Nat. Protoc. 10, 33-52 (2014).

33. Frunzke, J., Engels, V., Hasenbein, S., Gätgens, C. \& Bott, M. Coordinated regulation of gluconate catabolism and glucose uptake in Corynebacterium glutamicum by two functionally equivalent transcriptional regulators, GntR1 and GntR2. Mol. Microbiol. 67, 305-322 (2007).

34. Singh, J. K., Makde, R. D., Kumar, V. \& Panda, D. SepF increases the assembly and bundling of FtsZ polymers and stabilizes FtsZ protofilaments by binding along its length. J. Biol. Chem. 283, 31116-31124 (2008).

35. Mosyak, L. et al. The bacterial cell-division protein ZipA and its interaction with an FtsZ fragment revealed by X-ray crystallography. EMBO J. 19, 3179-3191 (2000).

36. Szwedziak, P., Wang, Q., Freund, S. M. \& Löwe, J. FtsA forms actin-like protofilaments. EMBO J. 31, 2249-2260 (2012).

37. Schumacher, M. A., Huang, K.-H., Zeng, W. \& Janakiraman, A. Structure of the $\mathrm{Z}$ ring-associated protein, $\mathrm{ZapD}$, bound to the $\mathrm{C}$-terminal domain of the tubulin-like protein, FtsZ, suggests mechanism of $Z$ ring stabilization through FtsZ cross-linking. J. Biol. Chem. 292, 3740-3750 (2017).

38. Huang, K.-H., Durand-Heredia, J. \& Janakiraman, A. FtsZ ring stability: of bundles, tubules, crosslinks, and curves. J. Bacteriol. 195, 1859-1868 (2013).

39. Schumacher, M. A. \& Zeng, W. Structures of the nucleoid occlusion protein SlmA bound to DNA and the C-terminal domain of the cytoskeletal protein FtsZ. Proc. Natl Acad. Sci. USA 113, 4988-4993 (2016).
40. Addinall, S. G. \& Lutkenhaus, J. FtsA is localized to the septum in an FtsZdependent manner. J. Bacteriol. 178, 7167-7172 (1996).

41. Bisson-Filho, A. W. et al. Treadmilling by FtsZ filaments drives peptidoglycan synthesis and bacterial cell division. Science 355, 739-743 (2017).

42. Yang, X. et al. GTPase activity-coupled treadmilling of the bacterial tubulin FtsZ organizes septal cell wall synthesis. Science 355, 744-747 (2017).

43. Manuse, S., Fleurie, A., Zucchini, L., Lesterlin, C. \& Grangeasse, C. Role of eukaryotic-like serine/threonine kinases in bacterial cell division and morphogenesis. FEMS Microbiol. Rev. 40, 41-56 (2016).

44. Mitchison, T. \& Kirschner, M. Dynamic instability of microtubule growth. Nature 312, 237-242 (1984).

45. Osawa, M., Anderson, D. E. \& Erickson, H. P. Reconstitution of contractile FtsZ rings in liposomes. Science 320, 792-794 (2008).

46. Ramirez-Diaz, D. A. et al. Treadmilling analysis reveals new insights into dynamic FtsZ ring architecture. PLoS Biol. 16, e2004845-20 (2018).

47. Ramirez-Diaz, D. A., Merino-Salomon, A., Heymann, M. \& Schwille, P. Bidirectional FtsZ filament treadmilling promotes membrane constriction via torsional stress. bioRxiv, https://doi.org/10.1101/587790 (2019).

48. Krupka, M., Sobrinos-Sanguino, M., Jiménez, M., Rivas, G. \& Margolin, W. Escherichia coli ZipA organizes FtsZ polymers into dynamic ring-like protofilament structures. mBio, https://doi.org/10.1128/mBio.01008-18 (2018)

49. Caldas, P. et al. Cooperative ordering of treadmilling filaments in cytoskeletal networks of FtsZ and its crosslinker ZapA. Nat. Commun. 10, 5744 (2019).

50. Rivas, G. \& Minton, A. P. Macromolecular crowding in vitro, in vivo, and in between. Trends Biochem. Sci. 41, 970-981 (2016).

51. van den Berg, J., Boersma, A. J. \& Poolman, B. Microorganisms maintain crowding homeostasis. Nat. Rev. Microbiol. 15, 309-318 (2017).

52. Xiao, J. \& Goley, E. D. Redefining the roles of the FtsZ-ring in bacterial cytokinesis. Curr. Opin. Microbiol. 34, 90-96 (2016).

53. Keilhauer, C., Eggeling, L. \& Sahm, H. Isoleucine synthesis in Corynebacterium glutamicum: molecular analysis of the ilvB-ilvN-ilvC operon. J. Bacteriol. 175, 5595-5603 (1993).

54. Ravasi, P., Peiru, S., Gramajo, H. \& Menzella, H. G. Design and testing of a synthetic biology framework for genetic engineering of Corynebacterium glutamicum. Microb. Cell Fact. 11, 1-1 (2012).

55. Lausberg, F., Chattopadhyay, A. R., Heyer, A., Eggeling, L. \& Freudl, R. A tetracycline inducible expression vector for Corynebacterium glutamicum allowing tightly regulable gene expression. Plasmid 68, 142-147 (2012).

56. Bindels, D. S. et al. mScarlet: a bright monomeric red fluorescent protein for cellular imaging. Nat. Methods 14, 53-56 (2016)

57. Shaner, N. C. et al. A bright monomeric green fluorescent protein derived from Branchiostoma lanceolatum. Nat. Methods 10, 407-409 (2013)

58. Baumgart, M., Schubert, K., Bramkamp, M. \& Frunzke, J. Impact of LytR CpsA-Psr proteins on cell wall biosynthesis in Corynebacterium glutamicum. J. Bacteriol. 198, 3045-3059 (2016).

59. Studier, F. W. Protein production by auto-induction in high density shaking cultures. Protein Expr. Purif. 41, 207-234 (2005).

60. Kabsch, W. XDS. Acta Crystallogr. D66, 125-132 (2010).

61. Winn, M. D. et al. Overview of the CCP4 suite and current developments. Acta Crystallogr. D67, 235-242 (2011).

62. McCoy, A. J. et al. Phaser crystallographic software. J. Appl. Crystallogr. 40, 658-674 (2007)

63. Schneider, T. R. \& Sheldrick, G. M. Substructure solution with SHELXD. Acta Crystallogr. D58, 1772-1779 (2002).

64. Cowtan, K. The Buccaneer software for automated model building. 1. Tracing protein chains. Acta Crystallogr. D62, 1002-1011 (2006)

65. Emsley, P. \& Cowtan, K. Coot: model-building tools for molecular graphics. Acta Crystallogr. D60, 2126-2132 (2004).

66. Bricogne, G. et al. Buster version 2.10.3. (Global Phasing Ltd, Cambridge, United Kingdom, 2017)

67. Pettersen, E. F. et al. UCSF Chimera: a visualization system for exploratory research and analysis. J. Comput. Chem. 25, 1605-1612 (2004)

68. Voegele, A., Subrini, O., Sapay, N., Ladant, D. \& Chenal, A. Membrane-active properties of an amphitropic peptide from the CyaA toxin translocation region. Toxins $\mathbf{9}, 369$ (2017).

69. Jomain, J.-B. et al. Structural and thermodynamic bases for the design of pure prolactin receptor antagonists: X-ray structure of Del1-9-G129R-hPRL. J. Biol. Chem. 282, 33118-33131 (2007)

70. Schindelin, J. et al. Fiji: an open-source platform for biological-image analysis. Nat. Methods 9, 676-682 (2012).

71. Ducret, A., Quardokus, E. M. \& Brun, Y. V. MicrobeJ, a tool for high throughput bacterial cell detection and quantitative analysis. Nat. Microbiol. 1, 1-7 (2016).

72. Carvalho, P. C. et al. Integrated analysis of shotgun proteomic data with PatternLab for proteomics 4.0. Nat. Protoc. 11, 102-117 (2015).

73. Micsonai, A. et al. Accurate secondary structure prediction and fold recognition for circular dichroism spectroscopy. Proc. Natl Acad. Sci. USA 112, E3095-E3103 (2015). 
74. Eddy, S. R. Profile hidden Markov models. Bioinformatics 14, 755-763 (1998).

75. Li, W. \& Godzik, A. Cd-hit: a fast program for clustering and comparing large sets of protein or nucleotide sequences. Bioinformatics 22, 1658-1659 (2006).

76. Steinegger, M. \& Söding, J. MMseqs2 enables sensitive protein sequence searching for the analysis of massive data sets. Nat. Biotechnol. 35, 1026-1028 (2017).

77. Katoh, K. \& Standley, D. M. MAFFT: iterative refinement and additional methods. Methods Mol. Biol. 1079, 131-146 (2013).

78. Capella-Gutierrez, S., Silla-Martinez, J. M. \& Gabaldon, T. TrimAl: a tool for automated alignment trimming in large-scale phylogenetic analyses. Bioinformatics 25, 1972-1973 (2009).

79. Guindon, S. et al. New algorithms and methods to estimate maximumlikelihood phylogenies: assessing the performance of PhyML 3.0. Syst. Biol. 59, 307-321 (2010).

80. Lefort, V., Longueville, J.-E. \& Gascuel, O. SMS: smart model selection in PhyML. Mol. Biol. Evol. 34, 2422-2424 (2017).

\section{Acknowledgements}

We thank A. Ducret for help with MicrobeJ, F. Gubellini for help with electron microscopy, M. Bott and M. Baumgart for the pk19-P3323-lcpA plasmid and help with corynebacterial genetics, and H. Gramajo for the pTGR5 plasmid. We gratefully acknowledge the core facilities at the Institut Pasteur C2RT, in particular G. PehauArnaudet (UBI), B. Raynal, S. Brule (PFBMI), P. Weber, C. Pissis (PFC), and J. Fernandes (UtechS PBI/Imagopole, supported by France BioImaging; ANR-10-INSB-04; Investments for the Future). We thank the staff of ESRF and of EMBL-Grenoble for assistance and support in using beamlines ID30B and ID23-1, and the staff of SOLEIL Synchrotron for assistance in using the beamline Disco. We acknowledge the PICT-IBISA for providing access to the cryo-EM facility at Orsay. Finally, we would like to thank the reviewers for their coments and suggestions, which have helped us to improve the quality of the manuscript. This work was partially supported by grants from the Institut Pasteur (Paris), the CNRS (France) and the Agence Nationale de la Recherche (PhoCellDiv, ANR-18-CE11-0017-01). A.S. is part of the Pasteur-Paris University (PPU) International Ph.D Program, funded by the European Union's Horizon 2020 research and innovation program under the Marie Sklodowska-Curie grant agreement No 665807. Q.G. was funded by MTCI Ph.D school (ED 563); A.V. was supported by a DIM MalInf (infectious diseases) grant. M.G. acknowledges support from Programa de Desarrollo de las Ciencias Básicas and Sistema Nacional de Investigación e Innovación, Uruguay.

\section{Author contributions}

A.M.W. and P.M.A. designed the research. A.S., M.M., Q.G., M.B.A. and A.M.W. conducted the protein biochemistry, cell biology and genetic experiments, and purified proteins for structural and biophysical studies. P.E. and A.S. carried out the biochemical and biophysical studies of protein-protein interactions. A.V, A.C., and A.S. carried out binding studies of lipid membrane-protein interactions. A.M.W. and R.D. carried out MS and proteomic experiments. A.S., A.H., A.M.W., and P.M.A. carried out the crystallogenesis and crystallographic studies. M.G. and A.M.W. performed the phylogeny analyses. M.V.N. contributed essential reagents (fluorescent labeled amino acids). A.S., S.T., and A.M.W. performed the cryo-EM and negative stain EM studies. A.M.W. and P.M.A. wrote the paper. All authors edited the paper.

\section{Competing interests}

The authors declare no competing interests.

\section{Additional information}

Supplementary information is available for this paper at https://doi.org/10.1038/s41467020-15490-8.

Correspondence and requests for materials should be addressed to A.M.W. or P.M.A.

Peer review information Nature Communications thanks Sebastien Pichoff, Hiroyoshi Matsumura and the other, anonymous, reviewer for their contribution to the peer review of this work. Peer reviewer reports are available.

Reprints and permission information is available at http://www.nature.com/reprints

Publisher's note Springer Nature remains neutral with regard to jurisdictional claims in published maps and institutional affiliations.

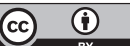

Open Access This article is licensed under a Creative Commons Attribution 4.0 International License, which permits use, sharing, adaptation, distribution and reproduction in any medium or format, as long as you give appropriate credit to the original author(s) and the source, provide a link to the Creative Commons license, and indicate if changes were made. The images or other third party material in this article are included in the article's Creative Commons license, unless indicated otherwise in a credit line to the material. If material is not included in the article's Creative Commons license and your intended use is not permitted by statutory regulation or exceeds the permitted use, you will need to obtain permission directly from the copyright holder. To view a copy of this license, visit http://creativecommons.org/ licenses/by/4.0/.

(C) The Author(s) 2020 